\title{
Storage and transformation of organic matter fractions in cryoturbated permafrost soils across the Siberian Arctic
}

\author{
N. Gentsch ${ }^{1}$, R. Mikutta ${ }^{1,2}$, R. J. E. Alves ${ }^{3}$, J. Barta ${ }^{4}$, P. Capek $^{4}$, A. Gittel ${ }^{5}$, G. Hugelius ${ }^{6}$, P. Kuhry ${ }^{6}$, N. Lashchinskiy ${ }^{7}$,

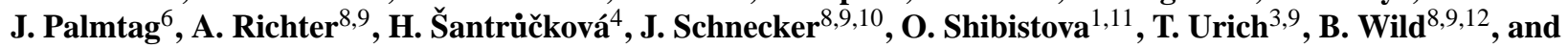 \\ G. Guggenberger ${ }^{1,11}$ \\ ${ }^{1}$ Institute of Soil Science, Leibniz Universität Hannover, Hanover, Germany \\ ${ }^{2}$ Soil Sciences, Martin Luther Universität Halle-Wittenberg, Halle, Germany \\ ${ }^{3}$ University of Vienna, Department of Ecogenomics and Systems Biology, Vienna, Austria \\ ${ }^{4}$ University of South Bohemia, Department of Ecosystems Biology, České Budéjovice, Czech Republic \\ ${ }^{5}$ Aarhus University, Center for Geomicrobiology, Aarhus, Denmark \\ ${ }^{6}$ Stockholm University, Department of Physical Geography and Quaternary Geology, Stockholm, Sweden \\ ${ }^{7}$ Central Siberian Botanical Garden, Siberian Branch of Russian Academy of Sciences, Novosibirsk, Russia \\ ${ }^{8}$ University of Vienna, Department of Microbiology and Ecosystem Science, Vienna, Austria \\ ${ }^{9}$ Austrian Polar Research Institute, Vienna, Austria \\ ${ }^{10}$ University of New Hampshire, Department of Natural Resources and the Environment, Durham, NH, USA \\ ${ }^{11}$ V.N. Sukachev Institute of Forest, Siberian Branch of Russian Academy of Sciences, Krasnoyarsk, Russia \\ ${ }^{12}$ University of Gothenburg, Department of Earth Sciences, Gothenburg, Sweden
}

Correspondence to: N. Gentsch (gentsch@ifbk.uni-hannover.de)

Received: 25 November 2014 - Published in Biogeosciences Discuss.: 06 February 2015

Revised: 23 June 2015 - Accepted: 24 June 2015 - Published: 30 July 2015

\begin{abstract}
In permafrost soils, the temperature regime and the resulting cryogenic processes are important determinants of the storage of organic carbon (OC) and its small-scale spatial variability. For cryoturbated soils, there is a lack of research assessing pedon-scale heterogeneity in OC stocks and the transformation of functionally different organic matter (OM) fractions, such as particulate and mineral-associated OM. Therefore, pedons of 28 Turbels were sampled in $5 \mathrm{~m}$ wide soil trenches across the Siberian Arctic to calculate OC and total nitrogen (TN) stocks based on digital profile mapping. Density fractionation of soil samples was performed to distinguish between particulate OM (light fraction, LF, $<1.6 \mathrm{~g} \mathrm{~cm}^{-3}$ ), mineral associated OM (heavy fraction, HF, $>1.6 \mathrm{~g} \mathrm{~cm}^{-3}$ ), and a mobilizable dissolved pool (mobilizable fraction, MoF). Across all investigated soil profiles, the total OC storage was $20.2 \pm 8.0 \mathrm{~kg} \mathrm{~m}^{-2}$ (mean $\pm \mathrm{SD}$ ) to $100 \mathrm{~cm}$ soil depth. Fifty-four percent of this OC was located in the horizons of the active layer (annual summer thawing layer), showing evidence of cryoturbation, and another $35 \%$ was present in the upper permafrost. The HF-OC dominated the
\end{abstract}

overall OC stocks (55\%), followed by LF-OC (19\% in mineral and $13 \%$ in organic horizons). During fractionation, approximately $13 \%$ of the $\mathrm{OC}$ was released as MoF, which likely represents a readily bioavailable OM pool. Cryogenic activity in combination with cold and wet conditions was the principle mechanism through which large OC stocks were sequestered in the subsoil $\left(16.4 \pm 8.1 \mathrm{~kg} \mathrm{~m}^{-2}\right.$; all mineral B, C, and permafrost horizons). Approximately $22 \%$ of the subsoil OC stock can be attributed to LF material subducted by cryoturbation, whereas migration of soluble $\mathrm{OM}$ along freezing gradients appeared to be the principle source of the dominant HF (63\%) in the subsoil. Despite the unfavourable abiotic conditions, low $\mathrm{C} / \mathrm{N}$ ratios and high $\delta^{13} \mathrm{C}$ values indicated substantial microbial OM transformation in the subsoil, but this was not reflected in altered LF and HF pool sizes. Partial least-squares regression analyses suggest that $\mathrm{OC}$ accumulates in the HF fraction due to co-precipitation with multivalent cations $(\mathrm{Al}, \mathrm{Fe})$ and association with poorly crystalline iron oxides and clay minerals. Our data show that, across all permafrost pedons, the mineral-associated OM represents the 
dominant $\mathrm{OM}$ fraction, suggesting that the HF-OC is the $\mathrm{OM}$ pool in permafrost soils on which changing soil conditions will have the largest impact.

\section{Introduction}

The storage and turnover of organic matter (OM) in Arctic soils has received broad interest due to the potential of permafrost environments to influence climate forces (Schaefer et al., 2011; UNEP, 2012). Earth history records have linked past extreme warming events to permafrost thaw and the release of greenhouse gasses from decomposing, previously frozen OM (DeConto et al., 2012). Similar signals for the onset of changing environmental conditions in these regions have been recently observed and include the degradation of continuous permafrost (Smith et al., 2005), an increase in active layer depth (the annual thawing layer), and rising permafrost temperatures (Fountain et al., 2012). Such changes will strongly affect all pedogenetic processes, including mineral weathering and $\mathrm{OM}$ cycling.

Alongside peat formation, cryoturbation is the major soilforming process in permafrost-affected soils and is primarily responsible for the distribution of OM within soil (Bockheim and Tarnocai, 1998). The principle mechanisms of cryopedogenic processes are based on frequent freezing-thawing cycles in combination with moisture migration along a thermal gradient (Bockheim et al., 1997). Cryoturbation leads to irregular or broken soil horizons as well as involutions and subduction of organic-rich materials from near-surface horizons to the subsoil. Pockets of topsoil (O and A horizons) material are incorporated into deeper mineral soil, including the upper part of the permafrost. Radiocarbon ages of several thousand years demonstrate that OM decomposition is hampered in cryoturbated materials as a result of the unfavourable abiotic conditions in deeper soil layers (Bockheim, 2007; Hugelius et al., 2010; Kaiser et al., 2007). Low and, for most of the year, subzero soil temperatures and frequent waterlogging during the short unfrozen period enable otherwise labile OM compounds to be preserved in the subsoil (Kaiser et al., 2007). Across the entire northern circumpolar permafrost region, approximately $400 \mathrm{Pg}$ of organic carbon (OC) and approximately $16 \mathrm{Pg}$ of nitrogen $(\mathrm{N})$ is estimated to be stored in cryoturbated soil horizons alone (Harden et al., 2012).

Increased subsoil temperatures, longer frost-free periods, and permafrost thaw might enhance the degradation of this preserved OM (Schuur et al., 2008). As microbial decomposition is more temperature-sensitive than primary production processes (Davidson and Janssens, 2006), this may generate a positive feedback of greenhouse gas emissions from permafrost areas to climate warming (Koven et al., 2011; Ping et al., 2015; Schuur et al., 2013; Schuur and Abbott, 2011). Recent concepts consider the persistence of soil OM to be an ecosystem property, primarily controlled by physicochemical and biological conditions rather than its molecular structure (Schmidt et al., 2011). Therefore, the magnitude of greenhouse gas emissions from permafrost regions depends not only on changes in soil environmental conditions but also on the contribution of different functional OM fractions, the operating protection mechanisms, and inherent kinetic properties. For temperate soils, it has been shown that interaction with mineral surfaces and metal ions, as well as physical stabilization by occlusion in soil aggregates, protect $\mathrm{OM}$ against decomposition (Kögel-Knabner et al., 2008; Von Lützow et al., 2006). Only a few studies have investigated different $\mathrm{OM}$ fractions in permafrost soils, and those have relied mainly on a select number of soil profiles (Dutta et al., 2006; Gentsch et al., 2015; Gundelwein et al., 2007; Höfle et al., 2013). Hence, data about pool sizes of different OM fractions, such as mineral- or metal-associated OM versus particulate OM (largely plant debris) on a larger spatial scale, are still missing. Moving forward in understanding high-latitude soil $\mathrm{OM}$ cycling requires an integration of studies that aim to upscale OC and TN stocks to the landscape and regional levels (Hugelius et al., 2014; Kuhry et al., 2010; Palmtag et al., 2015; Tarnocai et al., 2009) with more process-oriented pedon-scale studies.

Consequently, the objectives of this study were to (1) quantify OC and TN stocks in permafrost soils along a longitudinal gradient in the Siberian Arctic, with particular emphasis on the spatial distribution of cryoturbated topsoil material; (2) use density fractionation in combination with stable isotope $\left({ }^{13} \mathrm{C}\right)$ analyses to investigate the storage and transformation of $\mathrm{OC}$ in three different $\mathrm{OM}$ classes (i.e. potentially mobilizable dissolved OM, particulate, and mineralassociated $\mathrm{OM}$ ); and (3) investigate the relevance of mineral properties for the accumulation of OC in permafrost soils. To address these objectives, 28 soil pits located under tundra vegetation in western, central, and eastern Siberia were sampled and cryogenic features were mapped in each pedon over a distance of $5 \mathrm{~m}$ within the active layer. From these maps, we derived precise information about pedon-scale distribution and total storage of soil OC and TN. The mineralogical assemblage of the soils (clay mineral and metal oxide composition) was characterized by X-ray diffraction and selective extractions. The importance of mineral-organic associations for the accumulation of $\mathrm{OC}$ in the permafrost soils was assessed using multivariate statistical analyses to relate mineralogical properties to the quantity of mineral-associated OC.

\section{Materials and methods}

\subsection{Study area and soil sampling}

Soil samples were collected from nine sites on continuous permafrost in the Siberian Arctic (Fig. 1). The sampling sites were selected in different tundra types (Table 1 and detailed 


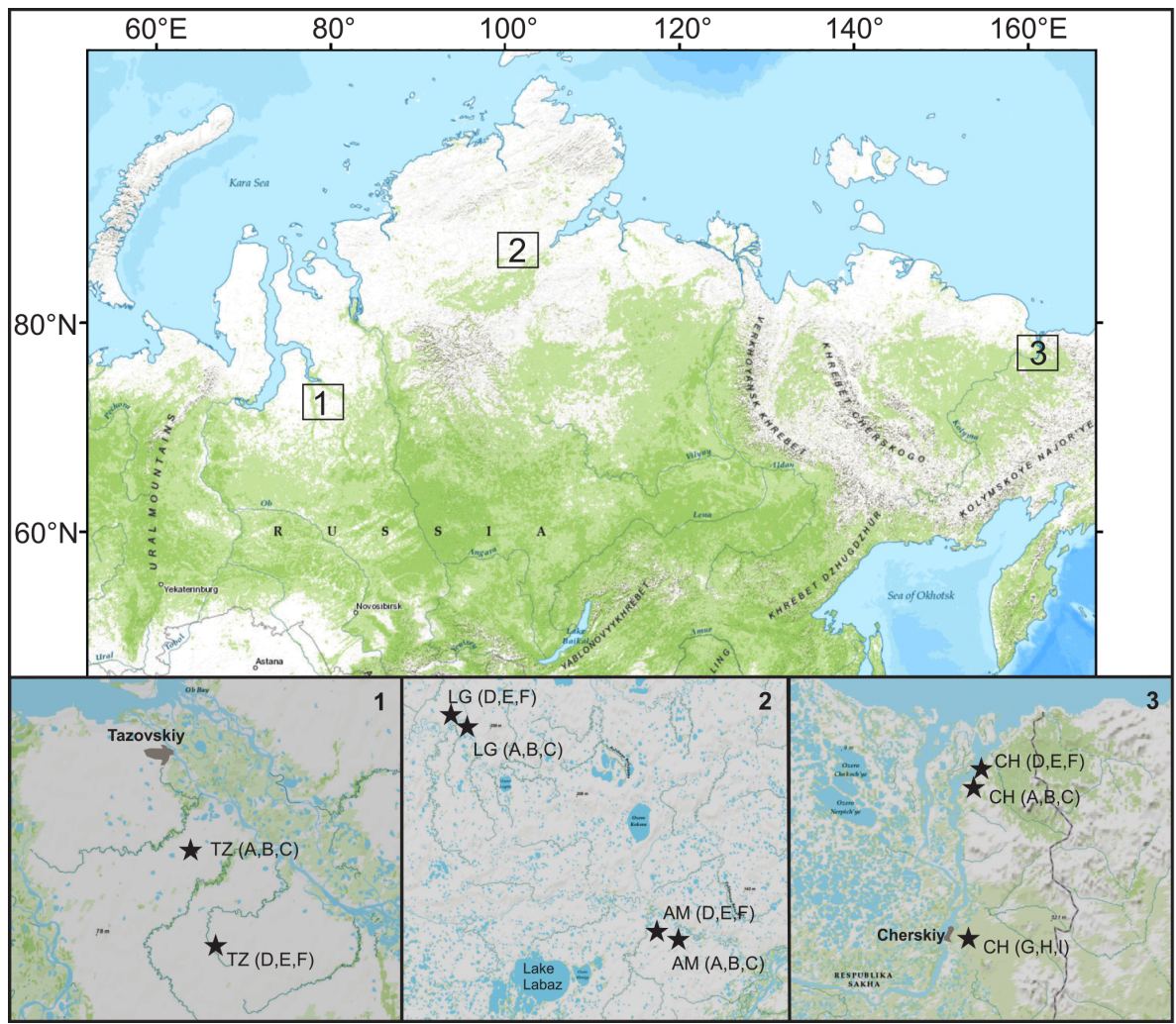

Figure 1. Sampling locations in western Siberia (1), central Siberia (2), and the Taimyr Peninsula and eastern Siberia (3). Each star marks a sampling site with three replicate soil profiles. Abbreviations are as follows: CH, Cherskiy; AM, Ari-Mas; LG, Logata; TZ, Tassovskiy (generated by ArcGIS 10)

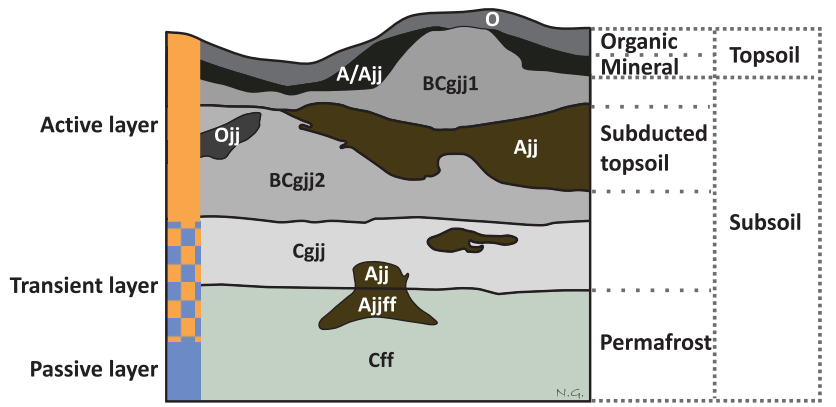

Figure 2. Overview of the soil diagnostic terminology used in this study. Horizon nomenclature according to Keys to Soil Taxonomy (Soil Survey Staff, 2010).

site description in the Supplement) in western (Tazowskiy, TZ), central (Ari-Mas, AM; Logata, LG), and eastern Siberia (Cherskiy, $\mathrm{CH}$ ). For comparability, all sampling sites were located in level areas. Soil profiles were excavated in at least three field replicates ( 28 profiles in total), with each replicate consisting of a $5 \times 1 \mathrm{~m}$ wide trench extending down to the permafrost table. The large dimension of the profiles provided a representative cross section through microtopographic features (hummocks, patterned ground) and cry- oturbation patterns. Soils were described according to Keys to Soil Taxonomy (Soil Survey Staff, 2010); a schematic overview of soil diagnostics and the terminology is summarized in Fig. 2.

Diagnostic horizons, including subducted topsoil material, were sampled at various positions within the soil profile. The upper permafrost layer was cored (up to $30-40 \mathrm{~cm}$ depth below the permafrost table) with a steel pipe at two positions in each profile: one directly underneath a hummock and the other in between the hummocks. Directly after sampling, living roots and animals were removed. An aliquot of the samples was then air-dried for transport to the laboratory, and the samples were sieved to $<2 \mathrm{~mm}$ if coarse rock fragments were present. Samples for the determination of bulk density (BD) were collected in triplicate over the $5 \mathrm{~m}$ profile in all diagnostic soil horizons using a $100 \mathrm{~cm}^{3}$ core cutter. Organic horizons were cut in dimensional blocks and measured by length, width, and height. All BD samples were dried at $105^{\circ} \mathrm{C}$ and $\mathrm{BD}$ was determined gravimetrically. In thin horizons, where it was impossible to extract a proper soil core, the BD of the surrounding mineral horizon was adopted and corrected for the respective OM content using the equation given by Rawls (1983). 


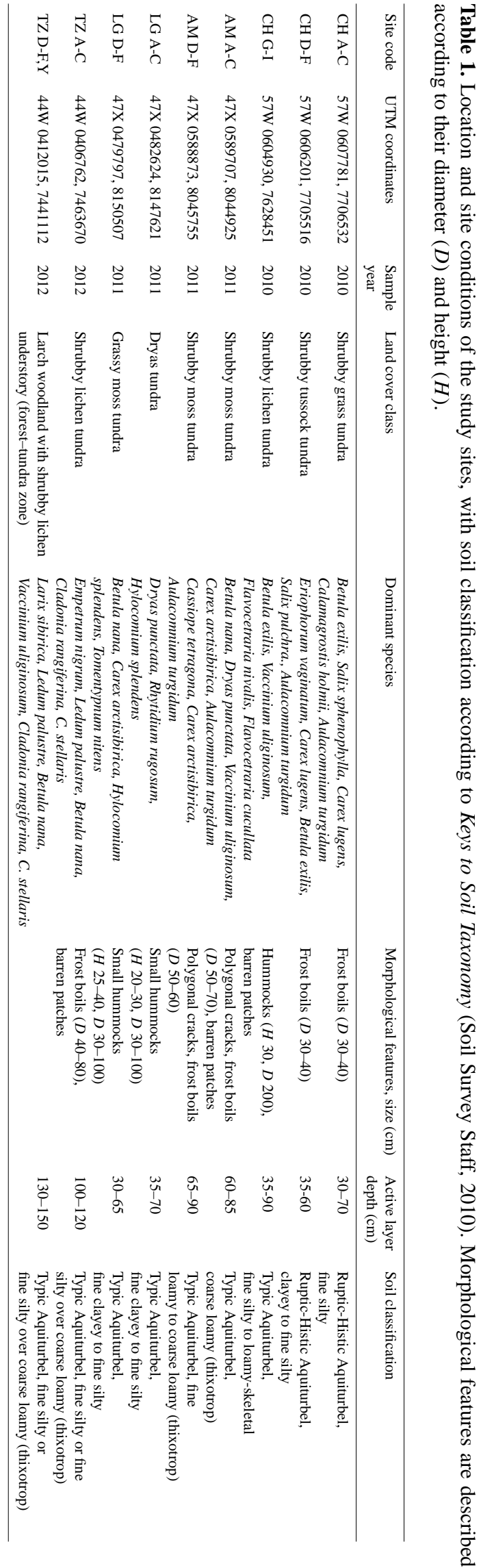

\subsection{Soil chemistry and mineralogy}

Soil $\mathrm{pH}$ was measured in suspension with $\mathrm{H}_{2} \mathrm{O}_{\text {deion }}$ at a soil-to-solution ratio of $1: 2.5$ (CG 842, Schott instruments, Mainz, Germany). Exchangeable cations were extracted with Mehlich 3 solution (for detailed methodology see Carter and Gregorich, 2008) and measured by inductively coupled plasma optical emission spectroscopy (ICP-OES; Varian 725-ES, Palo Alto, California). The effective cation exchange capacity $\left(\mathrm{CEC}_{\mathrm{eff}}\right)$ was calculated as the sum of exchangeable cations ( $\mathrm{Ca}, \mathrm{Mg}, \mathrm{K}, \mathrm{Na}, \mathrm{Al}, \mathrm{Fe}$, and $\mathrm{Mn}$ ) and the base saturation (BS) is expressed as the percentage of the basic cations $\left(\mathrm{Ca}, \mathrm{Mg}, \mathrm{K}\right.$, and $\mathrm{Na}$ ) to $\mathrm{CEC}_{\text {eff }}$.

Soil texture was analysed by means of the sieve-pipette method according to DIN ISO 11277 (2002) after OM oxidation with $30 \mathrm{wt} \%$ hydrogen peroxide and dispersion of residual soil aggregates in $0.05 \mathrm{M}$ sodium pyrophosphate. Iron and $\mathrm{Al}$ fractions in bulk soils were analysed using $0.2 \mathrm{M}$ ammonium oxalate ( $\mathrm{pH} \mathrm{2)}$ and sodium dithionite-citratebicarbonate (McKeague and Day, 1966). Oxalate-soluble Fe and $\mathrm{Al}\left(\mathrm{Fe}_{\mathrm{o}}, \mathrm{Al}_{\mathrm{o}}\right)$ represent poorly crystalline aluminosilicates, iron oxides such as ferrihydrite, and organically complexed Fe. Sodium dithionite dissolves all pedogenic oxides $\left(\mathrm{Fe}_{\mathrm{d}}\right)$, thus representing the total amount of poorly crystalline and crystalline iron oxides such as goethite, hematite, and ferrihydrite (Cornell and Schwertmann, 2003). As described by Eusterhues et al. (2008) and Lutwick and Dormaar (1973), sodium pyrophosphate $(0.1 \mathrm{M} ; \mathrm{pH} 10)$ was used to extract organically complexed $\mathrm{Fe}$ and $\mathrm{Al}$ from the heavy soil fractions (see Sect. 2.3). To avoid the mobilization of colloids (Parfitt and Childs, 1988), the extracts were ultracentrifuged at $300000 \mathrm{~g}$ for $6 \mathrm{~h}$. All extracts were measured for $\mathrm{Fe}$ and $\mathrm{Al}$ by ICP-OES (Varian 725-ES, Palo Alto, California). The activity index $\mathrm{Fe}_{\mathrm{o}} / \mathrm{Fe}_{\mathrm{d}}$ represents the proportion of poorly crystalline iron oxides (e.g. ferrihydrite) to the total free $\mathrm{Fe}$ (Cornell and Schwertmann, 2003). The proportion of well crystalline iron oxides can be described by the term $\mathrm{Fe}_{\mathrm{d}}-\mathrm{Fe}_{\mathrm{o}}$, whereas $\mathrm{Fe}_{\mathrm{o}}-\mathrm{Fe}_{\mathrm{p}}$ exclusively comprises the proportion of less crystalline $\mathrm{Fe}$ forms.

Clay-sized minerals $(<2 \mu \mathrm{m})$ were identified by $\mathrm{X}$-ray diffraction (XRD) analysis. Organic matter and iron oxides were removed by treatment with $6 \mathrm{wt} \%$ sodium hypochlorite (Moore and Reynolds, 1997) and sodium dithionitecitrate-bicarbonate, respectively. The clay fraction was isolated by sedimentation in Atterberg cylinders, according to Stoke's law, and saturated with either $\mathrm{K}^{+}$or $\mathrm{Mg}^{2+}$ (Moore and Reynolds, 1997). Oriented clay specimens were prepared by drying the clay suspension onto glass slide mounts. The samples were scanned between 1 and $32^{\circ} \theta$ with $0.05^{\circ} 2 \theta$ increment using a Kristalloflex D-500 spectrometer (Siemens AG, Munich, Germany). XRD scans were recorded for the following treatments: $\mathrm{K}$ saturation, $\mathrm{K}$ saturation with heating to $550^{\circ} \mathrm{C}, \mathrm{Mg}$ saturation, and $\mathrm{Mg}$ saturation with ethylene glycol treatment (Moore and Reynolds, 1997). 


\subsection{Soil fractionation and $\mathrm{OC}$ and TN determination}

Mineral soil horizons were fractionated by density according to Golchin et al. (1994) with some modifications. The light fraction $\mathrm{OM}\left(\mathrm{LF},<1.6 \mathrm{~g} \mathrm{~cm}^{-3}\right)$ was separated from the heavy fraction $\left(\mathrm{HF},>1.6 \mathrm{~g} \mathrm{~cm}^{-3}\right)$ by floating the sample in sodium polytungstate (SPT). Soil aggregates were destroyed by sonication (for details see Supplement Sect. S3). During washing of both fractions, considerable amounts of OM were mobilized. This "mobilizable fraction" (MoF) was collected separately, passed through syringe filters (PVDF, $<0.45 \mu \mathrm{m}$ ), and analysed for dissolved OC (LiquiTOC, Elementar, Hanau, Germany). The LF was imaged using a laser scanning microscope (Keyence VK-9700, Osaka, Japan), and scanning electron microscope images (FEI Quanta 200 FEG, Oregon, USA) were produced for both the LF and the HF.

Organic $\mathrm{C}$ and $\mathrm{TN}$ concentrations and the ${ }^{13} \mathrm{C}$ isotope content of bulk soils, as well as of the HF and LF fractions, were measured in duplicate using an Elementar IsoPrime 100 IRMS (IsoPrime Ltd, Cheadle Hulme, UK) coupled to an Elementar vario MICRO cube EA C / N analyser (Elementar Analysensysteme GmbH, Hanau, Germany). Before measurements, samples containing traces of carbonates were exposed to acid fumigation (Harris et al., 2001). Isotope values are expressed in the delta notation relative to the Vienna Pee Dee Belemnite (VPDB) standard (Hut, 1987).

OC and TN stocks of the cryoturbated soils were calculated using the sketch-based method described in Michaelson et al. (2001). Based on photo images taken during field excursions referenced by scaled drawings, detailed digital maps of soil horizons were generated using AutoCAD 2010 (Autodesk Inc., San Rafael, USA). From these maps, the horizon area $(A)$ of a certain diagnostic horizon was calculated as the sum of the individual shapes (Figs. 3 and S7). Organic C and TN stocks per designated horizon were calculated using Eq. (1) down to $100 \mathrm{~cm}$ soil depth, where $n$ is the number of designated horizons. Finally, the stocks were related to a $1 \mathrm{~m}^{2}$ soil surface.

$$
\begin{aligned}
& \mathrm{OC}_{\text {stock }}\left(\mathrm{kg} \mathrm{m}^{-2}\right)= \\
& \sum_{i=1}^{n} \mathrm{BD}\left(\mathrm{g} \mathrm{cm}^{-3}\right) \times \mathrm{OC}(\%) \times A\left(\mathrm{~m}^{2}\right) \times 10
\end{aligned}
$$

\subsection{Statistical analyses}

Statistical analyses were performed with SPSS 21 (IBM, Armonk, USA). All variables were tested for a normal distribution and log-transformed when required. Pearson correlation coefficients were calculated to describe linear relationships between parameters. The influence of soil horizons and sampling location on individual parameters (e.g. element content or isotopic ratios) was analysed using oneway and two-way analysis of variance (ANOVA). Following ANOVA, post hoc tests (Tukey's HSD) were conducted to
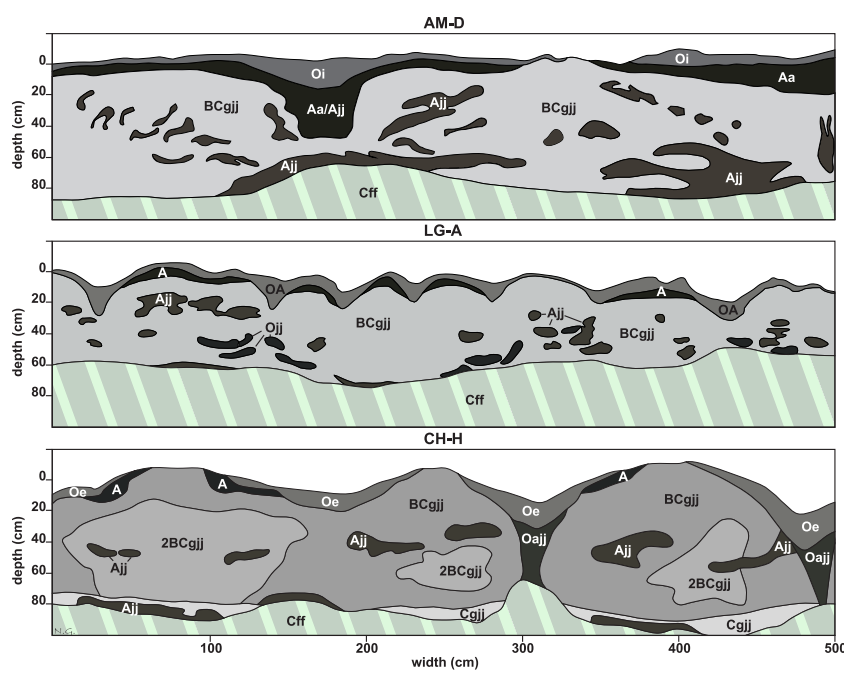

Figure 3. Selected profile maps from three different sampling sites at Cherskiy (CH), Ari-Mas (AM), and Logata (LG) (all other profile maps are presented in Fig. S7). Horizon symbols according to Keys to Soil Taxonomy (Soil Survey Staff, 2010). Note that the hatched areas (frozen zones) were not excavated, but cryoturbation also occurs in the upper permafrost, and subducted topsoil materials (Ojj, Ajj) can stretch into the permafrost.

identify subsets of sites or horizons $(p<0.05)$. Interactions of OC with soil mineral parameters were studied with partial least-squares regression (PLSR) analysis (for details see Supplement Sect. S2). Please note that the few Ojj horizons were combined with the Ajj horizons for statistical analyses.

\section{Results}

\subsection{Soil characteristics and morphology}

All soils were classified in the Aquiturbel great group (Soil Survey Staff, 2010) or characterized as cryohydromorphic soils (Sokolov et al., 2004), with aquic soil conditions being present in all soil profiles. In the upper $10-20 \mathrm{~cm}$ of the mineral soil, redoximorphic features were indicated by redox depletion and mottling (zones of Munsell soil colour value $\geq 4$ and chroma $<4$ ). Toward the permafrost surface, the soils showed strong reducing conditions, with low Munsell colour values $(\leq 4)$, low chroma (2), and, frequently, colour hues between $5 \mathrm{G}$ and 10BG. All soil profiles showed strong signs of cryoturbation by disrupted horizons or subducted OMrich pockets, involutions, or tongues (Figs. 3 and S7). Because samples from the permafrost were received by coring, the morphology of subducted topsoil materials could not be traced in the frozen parts of the profiles (e.g. Ajjff). Nevertheless, many profiles from central and eastern Siberia (profiles CH D-I, AM A-C, LG D; Fig. S7) contain a zone $20 \mathrm{~cm}$ above the permafrost table, and within the upper $10 \mathrm{~cm}$ of the permafrost that is enriched with OC (see Sect. 3.3). This 
zone is referred to as the "transient layer" (Fig. 2). This layer depends on decadal climate fluctuations (French and Shur, 2010) and shows pronounced signs of Fe reduction. For data evaluation, the following five horizon groups were distinguished: organic topsoil horizons $(\mathrm{Oa}, \mathrm{Oe}, \mathrm{Oi})$, mineral topsoil horizons $(\mathrm{A}, \mathrm{AB})$, cryoturbated OM-rich pockets in the subsoil (Ajj, Ojj, referred to as "subducted topsoil"), mineral subsoil horizons $(\mathrm{BCg}, \mathrm{BC}$, and $\mathrm{Cg}$ often showed signs of cryoturbation, shown with the suffix $\mathrm{jj}$, and permafrost horizons (commonly designated as $\mathrm{Cf}, \mathrm{Cff}$, but partly incorporate subducted topsoil materials).

The soils were loamy, clayey, or fine silty, with an absence of coarse materials, and were partly thixotropic. Rock fragments from the near-surface bedrock were only incorporated into profile $\mathrm{CH}-\mathrm{H}$ in eastern Siberia. The $\mathrm{CH}$ soils were all dominated by silt (Fig. S2), indicating an aeolian origin of the parent material. At the Taimyr Peninsula (central Siberian sites), the soils were rich in silt and clay (silty clay loam) at LG, but more sandy (sandy loam) at AM. Vertical textural differences (fine silty to coarse loamy) in TZ suggest distinct sedimentation conditions during deposition of the parent material and less cryogenic mixing in the deeper soil. Clay content increased in the order AM $(12 \pm 4 \%)$, TZ $(20 \pm 10 \%)$, $\mathrm{CH}(21 \pm 8 \%)$, and LG $(27 \pm 6 \%)$.

The active layer depth in $\mathrm{CH}$ and Taymyr soils varied from 30 to $90 \mathrm{~cm}$, depending on the thickness of the organic layer and position. Small-scale variability in the thickness and the insulating effect of the organic layer associated with patterned ground formation (Ping et al., 2008) often caused a wavy upper boundary of the permafrost surface (Fig. 3). In contrast, the permafrost table of the $\mathrm{TZ}$ soil profiles was smooth and considerably deeper $(100-150 \mathrm{~cm})$. The surface morphology and horizon boundary of these soil layers were planar and less disturbed by cryoturbation (Fig. S7). The upper permafrost $(30-40 \mathrm{~cm})$ was recorded as dry permafrost (Cff) containing little vain ice and no massive ice bodies.

\subsection{Chemical soil parameters and mineral composition}

Topsoil $\mathrm{pH}$ ranged from strongly acidic in organic topsoil to slightly acidic in mineral topsoil horizons (Table S1). Subsoil $\mathrm{pH}$ increased with soil depth from slightly acidic in the upper active layer to neutral or moderately alkaline within permafrost horizons. The $\mathrm{CEC}_{\text {eff }}$ was larger only in the $\mathrm{LG}$ soils (Tukey's HSD, $p<0.001$ ), with an interquartile range from 20 to $34 \mathrm{cmol}_{\mathrm{c}} \mathrm{kg}^{-1}$ across all sites (Table S1), and no difference between soil horizons was evident. The BS varied from 33 to $88 \%$, and the dominating cations were $\mathrm{Ca}^{2+}$ (from 17 to $64 \%$ of $\mathrm{CEC}_{\text {eff }}$ ) and $\mathrm{Mg}^{2+}$ (from 8 to $33 \%$ of $\mathrm{CEC}_{\text {eff }}$ ) at all sites. Tukey's HSD indicated increasing BS in the order $\mathrm{CH}<\mathrm{TZ}<\mathrm{AM}<\mathrm{LG}$ and rising values towards the permafrost. Concurrently, exchangeable acid cations such as $\mathrm{Al}^{3+}$ (contributing from 11 to $64 \%$ to $\mathrm{CEC}_{\text {eff }}$ ) showed significantly smaller values at AM and LG compared with TZ and CH (Tukey's HSD, $p<0.001)$ and decreased with soil depth only at the latter sites.

In the $\mathrm{CH}$ soils, the clay fraction was composed of illite, vermiculite, kaolinite, and mixed-layer clays, with an increasing abundance of smectite clays towards the permafrost table (Fig. S4). Primary minerals such as quartz and traces of feldspars were also detected in all samples. Smectite minerals clearly dominated the clay fractions in central and western Siberian soils (Figs. S3 and S4). In addition, soils from AM contained illite, vermiculite, and kaolinite. The LG and TZ samples showed somewhat higher peak intensities for illite and kaolinite and an abundance of chlorite instead of vermiculite. The intensity of smectite signals increased strongly in the permafrost table at TZ, whereas chlorite was enriched in the upper active layer.

Pedogenic $\mathrm{Fe}$ and $\mathrm{Al}$ in the $\mathrm{CH}$ soils have already been presented in Gittel et al. (2014) and Gentsch et al. (2015). Dithionite-extractable $\mathrm{Fe}$ ranged from 1.7 to $26.4 \mathrm{~g} \mathrm{~kg}^{-1}$ (Table S2), and all sampling sites showed significant differences to each other (two-way ANOVA, $\mathrm{F}_{(3,127)}=113.7$, $p<0.001)$ but no variations with soil depth $\left(\mathrm{F}_{(3,127)}=1.0\right.$, $p=0.38)$. Oxalate-extractable $\mathrm{Fe}\left(0.7\right.$ to $\left.26.4 \mathrm{~g} \mathrm{~kg}^{-1}\right)$ and $\mathrm{Al}\left(0.02\right.$ to $\left.5.0 \mathrm{~g} \mathrm{~kg}^{-1}\right)$ varied significantly between sites and soil horizons (two-way ANOVA, $\mathrm{F}_{\mathrm{Fe}(9,128)}=2.7, p=0.005$, $\left.\mathrm{F}_{\mathrm{Al}(9,128)}=14.3, p<0.001\right)$. The largest content of $\mathrm{Fe}_{\mathrm{d}}, \mathrm{Fe}_{\mathrm{o}}$, and $\mathrm{Al}_{\mathrm{O}}$ was found in the $\mathrm{CH}$ soils and decreased in the order LG, TZ, and AM. Tukey's HSD indicated, as an overall trend, a significant enrichment of $\mathrm{Fe}_{\mathrm{o}}$ and $\mathrm{Al}_{\mathrm{o}}$ in subducted topsoil materials compared with the surrounding horizons $(p<0.05)$.

The concentrations of $\mathrm{Fe}$ in well crystalline oxides ranged from 0.8 to $6.0 \mathrm{~g} \mathrm{~kg}^{-1}$ and were largest at $\mathrm{CH}$ (Table S2). The smallest amounts were observed in subducted topsoil $\left(1.8 \pm 1.6 \mathrm{~g} \mathrm{~kg}^{-1}\right)$, but no clear differences were detected between the topsoil, subsoil (B / C), and the permafrost horizons. Concurrently, the activity index $\mathrm{Fe}_{\mathrm{o}} / \mathrm{Fe}_{\mathrm{d}}$ varied from 0.4 to 1.0 across soil horizons and sites with the highest values in subducted topsoils. Pyrophosphate-extractable $\mathrm{Fe}$ and $\mathrm{Al}$ ranged from 0.04 to 10.03 and 0.01 to $2.91 \mathrm{~g} \mathrm{~kg}^{-1}$, respectively. The highest concentrations were found at $\mathrm{CH}$ and LG, and subducted topsoils were significantly enriched (up to 7-fold) compared with surrounding subsoils (two-way ANOVA, Tukey's HSD, $p_{\mathrm{Fe}}<0.001, p_{\mathrm{Al}}<0.01$; Table S2).

\subsection{Organic carbon and total nitrogen storage and stable ${ }^{13} \mathrm{C}$ isotopic composition of the bulk soil}

The average OC and TN concentrations (Table S3) did not vary significantly across the four study areas for $\mathrm{O}$ and $\mathrm{A}$ horizons (Tukey's HSD, $p>0.05$ ). Please note that a portion of the bulk OC and TN data have been reported elsewhere (Gentsch et al., 2015; Gittel et al., 2014; Schnecker et al., 2014; Wild et al., 2013). Subducted topsoil horizons revealed twice as much $\mathrm{OC}$ and $\mathrm{TN}$ at $\mathrm{CH}$ and $\mathrm{LG}$ when compared with AM and TZ (Table S3). For B / C horizons, OC con- 
centrations were significantly larger at $\mathrm{CH}, \mathrm{AM}$, and LG, exceeding those at TZ soils by up to 5 times (Tukey's HSD, $p<0.05)$. This difference increased to factors of 8 to 11 in the permafrost horizons (Table S3).

The OC stocks to $1 \mathrm{~m}$ soil depth ranged from 6.5 to $36.4 \mathrm{~kg} \mathrm{~m}^{-2}$, with a mean value across all soils of $20.2 \pm 8.0 \mathrm{~kg} \mathrm{~m}^{-2}$ (Table 2). The soils in eastern $\left(\mathrm{CH}: 24.0 \pm 6.7 \mathrm{~kg} \mathrm{~m}^{-2}\right.$ ) and central Siberia (AM: $21.1 \pm 5.4 \mathrm{~kg} \mathrm{~m}^{-2}$; LG: $24.4 \pm 7.0 \mathrm{~kg} \mathrm{~m}^{-2}$ ) contained about twice as much $\mathrm{OC}$ as those sampled in western Siberia (TZ: $10.8 \pm 4.3 \mathrm{~kg} \mathrm{~m}^{-2}$ ). On average, $2.6 \pm 2.4 \mathrm{~kg} \mathrm{OC} \mathrm{m}^{-2}$ or $13 \%$ of the total OC was stored in the organic topsoil. The amount of OC stored in the mineral active layer was $11.5 \pm 3.8 \mathrm{~kg} \mathrm{~m}^{-2}(57 \%)$, of which $3.5 \pm 2.5 \mathrm{~kg} \mathrm{~m}^{-2}(18 \%)$ was located in subducted topsoil materials. The proportion of soil OC located in active layer horizons with signs of cryoturbation (include $\mathrm{Ajj}$, Ojj, BCgjj, and $\mathrm{Cgjj}$ horizons) ranged from 33 to $83 \%$ with an average of $54 \%$. All mineral subsoil horizons, including permafrost, stored $16.4 \pm 8.1 \mathrm{~kg} \mathrm{OC} \mathrm{m}^{-2}$ ( $81 \%$ of the total soil OC). Within the first soil metre, the eastern and central Siberian soils stored $8.1 \pm 5.5 \mathrm{~kg} \mathrm{OC} \mathrm{m}^{-2}$ $(35 \%)$ in the upper permafrost. Due to the large active layer thickness in the western Siberian soils, no OC was located in the permafrost within the examined soil depth.

The $\delta^{13} \mathrm{C}$ ratios of soil OC (Fig. 4) showed significant differences between sites and genetic horizons, representing soil depth categories (two-way ANOVA, $\mathrm{F}_{(12,324)}=4.4$, $p<0.001)$. Overall, bulk OC showed increasing $\delta^{13} \mathrm{C}$ ratios from eastern to western Siberia, with no difference between the two central Siberian sites. The $\delta^{13} \mathrm{C}$ values generally increased with soil depth $(\mathrm{O}<\mathrm{A}, \mathrm{Ajj} / \mathrm{Ojj}<\mathrm{B} / \mathrm{C}<\mathrm{Cff}$, Tukey's HSD, $p<0.05$ ), and no difference was observed between topsoils and subducted topsoil horizons (Tukey's HSD, $p=$ 0.99). Concurrently, $\mathrm{C} / \mathrm{N}$ ratios decreased with soil depth (Fig. 4; ANOVA, $\mathrm{F}_{(4,333)}=81.9, p<0.001$ ), with no differences between topsoil horizons and subducted topsoils (Tukey's HSD, $p=1$ ) or between B / C horizons and the upper permafrost layer (Tukey's HSD, $p=1$ ).

The TN stocks of the bulk soil increased from $0.8 \pm 1.4 \mathrm{~kg}$ $\mathrm{m}^{-2}$ in $\mathrm{TZ}$ to $1.3 \pm 0.3$ and $1.7 \pm 0.3 \mathrm{~kg} \mathrm{~m}^{-2}$ in $\mathrm{AM}$ and $\mathrm{LG}$, and $1.8 \pm 0.4 \mathrm{~kg} \mathrm{~m}^{-2}$ in $\mathrm{CH}$, with an average of $1.4 \pm 0.5 \mathrm{~kg} \mathrm{TN} \mathrm{m}^{-2}$ across all soils (Table 2). On average, $0.1 \pm 0.1 \mathrm{~kg} \mathrm{TN} \mathrm{m}^{-2}(7 \%)$ was stored in the organic layer and $0.9 \pm 0.2 \mathrm{~kg} \mathrm{TN} \mathrm{m}^{-2}(61 \%)$ was stored in the mineral active layer, of which $0.2 \pm 0.1 \mathrm{~kg} \mathrm{~m}^{-2}(15 \%)$ was located in subducted topsoils. In the eastern and central Siberian soils, $0.5 \pm 0.4 \mathrm{~kg} \mathrm{TN} \mathrm{m}^{-2}(32 \%)$ was found in the permafrost layer.

\subsection{Organic carbon and total nitrogen storage in organic matter fractions}

At $\mathrm{AM}, \mathrm{LG}$, and $\mathrm{CH}$, the relative proportion of $\mathrm{LF}-\mathrm{OC}$ to the bulk OC increased from $24 \%$ in topsoil to $30 \%$ in subducted topsoil horizons (Table S3). The permafrost horizons stored
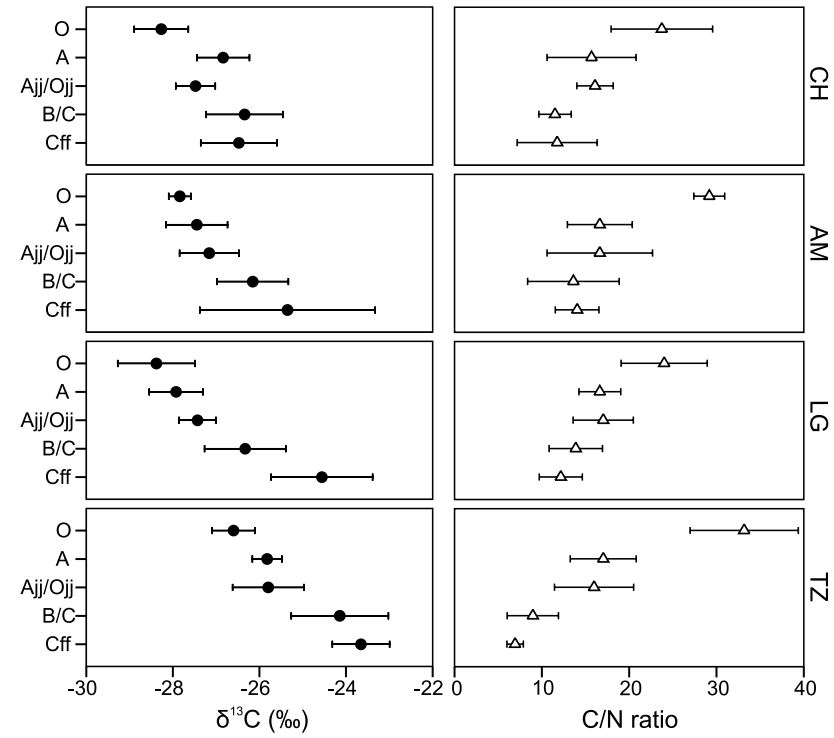

Figure 4. Vertical pattern of $\delta^{13} \mathrm{C}$ values and $\mathrm{C} / \mathrm{N}$ ratios of bulk soils with respect to different sampling sites and soil horizon clusters (mean $\pm \mathrm{SD} ; n$ is given in Table $\mathrm{S} 1$ ).

relatively more $\mathrm{OC}$ in the $\mathrm{LF}$ than the overlying mineral subsoils (21 vs. $16 \%)$. In contrast, in soils from TZ with the permafrost table at $>100 \mathrm{~cm}$ soil depth, the relative storage of LF-OC decreased continuously from the topsoil (23\%) towards the permafrost (11\%).

When considering the organic layers and the different OM fractions in the mineral soil across all study sites (Table 2 and Fig. 8), the average storage of $20.2 \pm 8.0 \mathrm{~kg} \mathrm{OC} \mathrm{m}^{-2}$ within $1 \mathrm{~m}$ soil depth can be separated into the following fractions: organic layer $2.6 \pm 2.4 \mathrm{~kg} \mathrm{~m}^{-2}(13 \%)$, LF $3.8 \pm 2.3 \mathrm{~kg} \mathrm{~m}^{-2}(19 \%), \mathrm{HF} 11.1 \pm 5.0 \mathrm{~kg} \mathrm{~m}^{-2}(55 \%)$, and MoF $2.7 \pm 1.8 \mathrm{~kg} \mathrm{~m}^{-2}(13 \%)$. With the exception of the AM soils, the contribution of the individual fractions to total stocks was quite constant between profiles, with no major deviation from the mean percentage of HF (ANOVA, $\left.\mathrm{F}_{(3,24)}=0.98, p=0.42\right)$ and $\mathrm{MoF}\left(\mathrm{ANOVA}, \mathrm{F}_{(3,24)}=1.16\right.$, $p=0.35)$. Only the AM soils contained on average $47 \%$ more LF-OC than the other sites (ANOVA, $\mathrm{F}_{(3,24)}=6.63$, $p<0.01)$. This larger value was primarily due to a larger LF storage in subducted topsoil (Table 2). All mineral subsoil horizons including permafrost stored on average $3.6 \pm 2.3 \mathrm{~kg} \mathrm{OC} \mathrm{m}^{-2}$ as LF, $10.3 \pm 4.9 \mathrm{~kg} \mathrm{OC} \mathrm{m}^{-2}$ as HF, and $2.6 \pm 1.8 \mathrm{~kg} \mathrm{OC} \mathrm{m}^{-2}$ as $\mathrm{MoF}$, corresponding to a contribution of 22,63 , and $15 \%$ of the total subsoil OC. Remarkably, at AM and LG, up to 3 times more particulate OM was located in the subsoil as LF-OC than was found as LF-OC in the mineral topsoil and the organic layer combined. The permafrost horizons at $\mathrm{CH}, \mathrm{AM}$, and $\mathrm{LG}$ stored on average $1.8 \pm 1.9 \mathrm{~kg} \mathrm{OC} \mathrm{m}^{-2}$ as LF, $5.0 \pm 3.1 \mathrm{~kg} \mathrm{OC} \mathrm{m}^{-2}$ as $\mathrm{HF}$, and $1.3 \pm 1.3 \mathrm{~kg} \mathrm{OC} \mathrm{m}^{-2}$ as MoF, which contributes 40,38 , and $41 \%$ of the individual fraction within the whole soil. 
Table 2. Mean soil OC and TN stocks $(0-100 \mathrm{~cm})$ with respect to different sampling sites and soil horizons plus standard deviation (SD). Bulk values (unfractionated stocks) were separated into light fraction (LF), heavy fraction (HF), and the mobilized fraction (MoF). The total bulk values include the organic topsoil.

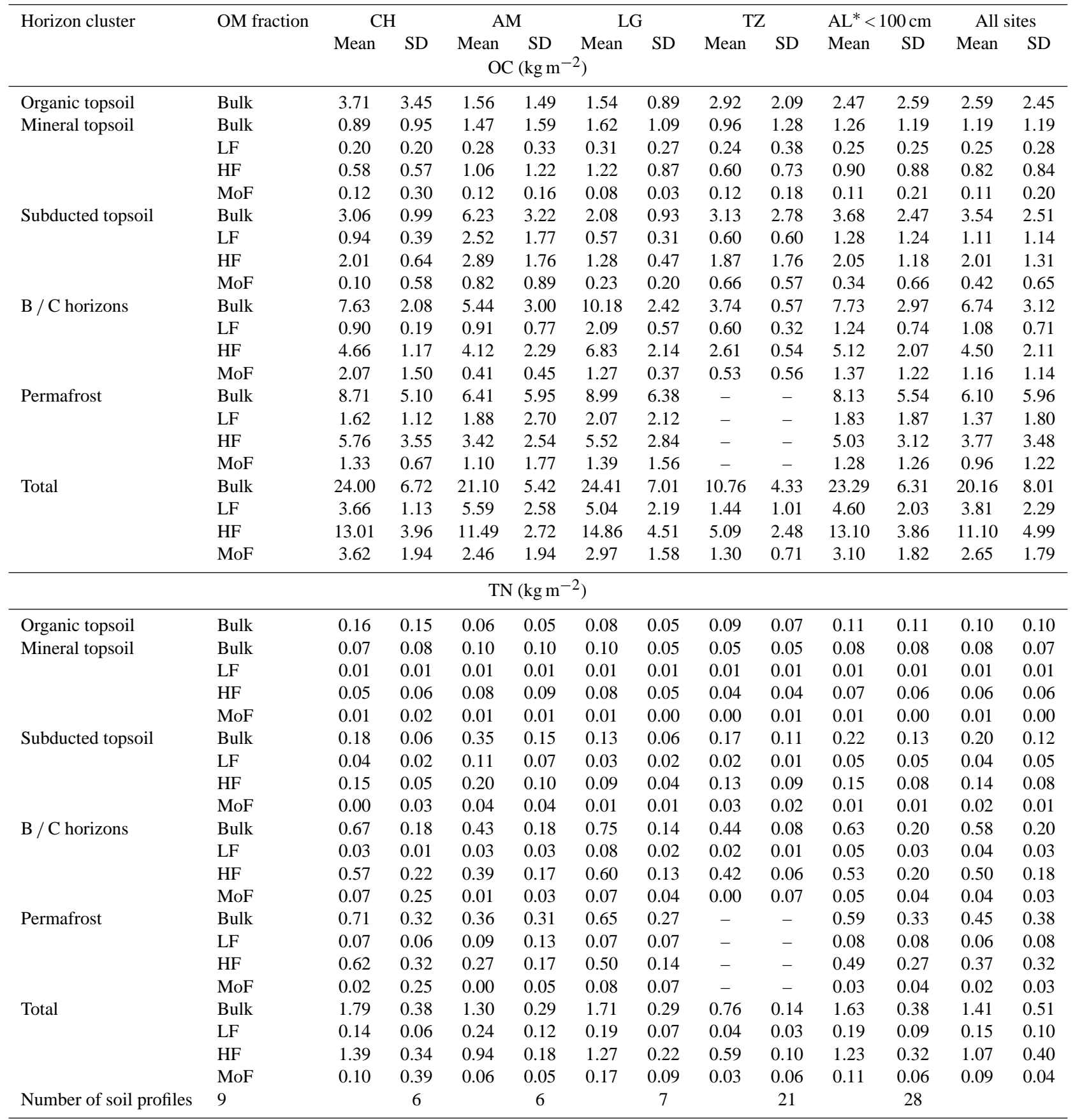

* Only include profiles from AM, LG, and CH with active layer $(\mathrm{AL})<100 \mathrm{~cm}$.

Compared with OC, relatively more $\mathrm{TN}$ was located in the mineral-associated fraction. The average storage of $\mathrm{TN}$ in the bulk soil was $1.41 \pm 0.51 \mathrm{~kg} \mathrm{~m}^{-2}$, with the HF containing $1.07 \pm 0.40 \mathrm{~kg} \mathrm{TN} \mathrm{m}^{-2}$ (76\%). Only $0.10 \pm 0.10 \mathrm{~kg} \mathrm{TN} \mathrm{m}^{-2}(7 \%)$ was stored in the organic layers and $0.15 \pm 0.10 \mathrm{~kg} \mathrm{TN} \mathrm{m}^{-2}(10 \%)$ was isolated as LF.
The mobilized TN in the rinsing solutions could not be measured directly due to detector problems, but was calculated based on mass balance. On average, $0.09 \pm 0.13 \mathrm{~kg} \mathrm{~m}^{-2}$ $(6 \%)$ of the total $\mathrm{TN}$ stocks was mobilized. The $\mathrm{TN}$ in all subsoil horizons was present as $0.14 \pm 0.10 \mathrm{~kg} \mathrm{~m}^{-2} \mathrm{LF}$, $1.01 \pm 0.39 \mathrm{~kg} \mathrm{~m}^{-2} \mathrm{HF}$, and $0.08 \pm 0.04 \mathrm{~kg} \mathrm{~m}^{-2} \mathrm{MoF}$, which 
contributes 11,82 , and $7 \%$ of the total subsoil stocks. The permafrost horizons at $\mathrm{CH}, \mathrm{AM}$, and $\mathrm{LG}$ stored on average $0.08 \pm 0.08 \mathrm{~kg} \mathrm{TN} \mathrm{m}^{-2}$ in the LF, $0.49 \pm 0.29 \mathrm{~kg} \mathrm{TN} \mathrm{m}^{-2}$ as $\mathrm{HF}$, and $0.03 \pm 0.07 \mathrm{~kg} \mathrm{TN} \mathrm{m}^{-2}$ as MoF, which represents 41 , 40 , and $29 \%$ of the individual fraction within the whole soil.

\subsection{Composition of LF and HF}

The LF was primarily composed of discrete debris of plants and microorganisms. Confocal laser scanning microscope images show remnants of leaves, fine roots, wood, and bark from dwarf shrubs and hyphae of fungi (Fig. 5). The particle size of these materials is not related to depth. Coarse plant fragments $(>1 \mathrm{~mm})$ were observed in whole soil profiles including the permafrost. The LF was composed of fairly welldecomposed particles $(<1 \mathrm{~mm})$ in organic layers and topsoils (Oa, Oe, OA) at the rim of hummocks to frost cracks or in subducted topsoils at various depths. In contrast to the heterogeneous LF particle size distribution in subducted topsoils, the LF in B and C horizons was very uniform and coarse fragments were missing. Scanning electron microscope images of the HF (Fig. S8; panel a and b) showed that soil aggregates were largely disrupted after density treatment and that the LF floated properly in the SPT. The images also indicate amorphous structures which were associated with primary mineral particles of different sizes.

Compared with the $\mathrm{HF}$, which showed narrow $\mathrm{C} / \mathrm{N}$ ratios and substantial enrichment in ${ }^{13} \mathrm{C}(1.38 \pm 0.14 \%$ in average), the $\mathrm{C} / \mathrm{N}$ and $\delta^{13} \mathrm{C}$ ratios of the $\mathrm{LF}$ were closer to the ranges observed in organic topsoil and the plant residues from which they derived (Fig. 6). Tukey's HSD indicated no difference in $\delta^{13} \mathrm{C}$ values of the LF and HF between central and eastern Siberian soils $\left(p_{\mathrm{LF}}=0.17, p_{\mathrm{HF}}=0.37\right)$ but significant differences in $\delta^{13} \mathrm{C}$ values between soils in these two regions and the western Siberian soils $\left(p_{\mathrm{LF}}<0.001\right.$, $\left.p_{\mathrm{HF}}<0.001\right)$. Here, the $\delta^{13} \mathrm{C}$ values of the $\mathrm{LF}$ and $\mathrm{HF}$ were on average $1.38 \pm 0.14$ and $1.04 \pm 0.14 \%$, respectively, more positive than those in the central and eastern Siberian soils. This effect can be explained by the larger ${ }^{13} \mathrm{C}$ content of the source plants at TZ, which had more positive $\delta^{13} \mathrm{C}$ values ( $\Delta=0.44$ to $2.55 \%$ o) than at the central and eastern Siberian sites (Fig. S6). The $\delta^{13} \mathrm{C}$ values of the $\mathrm{LF}$ increased in the order $\mathrm{A}<\mathrm{Ajj} / \mathrm{Ojj}<\mathrm{B} / \mathrm{C}$ and Cff, with no difference among B / C and Cff horizons (Tukey's HSD, $p=0.98)$. Further, Tukey's HSD grouped two subsets of $\delta^{13} \mathrm{C}$ values for the HF. Less negative $\delta^{13} \mathrm{C}$ values were found in the $\mathrm{B} / \mathrm{C}$ and the Cff horizons (Tukey's HSD, $p=0.98$ ) and more negative values were detected in the $\mathrm{A}$ and $\mathrm{Ajj} / \mathrm{Ojj}$ horizons (Tukey's HSD, $p=0.49$ ).
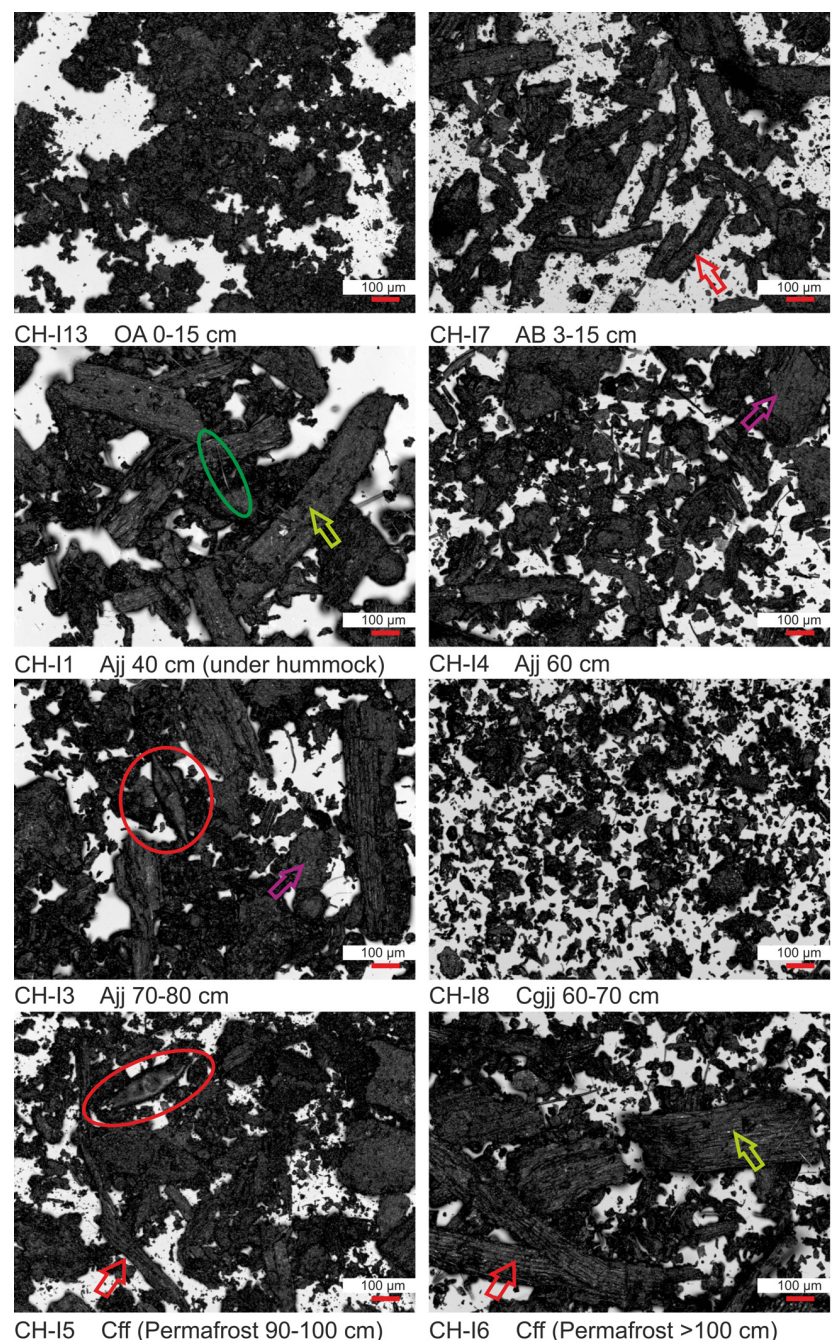

Figure 5. Laser scanning microscope images from the LF for one profile in western Siberia. The images were arranged according to the increasing soil depth of various genetic horizons. Red, green, and purple arrows denote fine roots, woody tissue, and bark, respectively. Red and green circles denote seeds and fungal hyphae, respectively.

\subsection{Organic matter in mineral-organic associations}

Across all sampling sites, the concentration of HF-OC was highly correlated with the concentration of $\mathrm{Fe}_{p}(r=0.83$, $p<0.001)$ and $\mathrm{Al}_{p}(r=0.72, p<0.001)$, thus supporting the use of $\mathrm{Fe}_{p}$ and $\mathrm{Al}_{p}$ as indicators for organically complexed metals (Fig. S5). To identify preferred interaction of OC with different mineral parameters $\left(\mathrm{Fe}_{\mathrm{d}}-\mathrm{Fe}_{\mathrm{o}}, \mathrm{Fe}_{\mathrm{o}}-\mathrm{Fe}_{p}\right.$, $\mathrm{Al}_{\mathrm{o}}-\mathrm{Al}_{p}, \mathrm{Fe}_{p}, \mathrm{Al}_{p}$, clay- and clay+silt-sized minerals), we performed PLSR analyses with $\mathrm{HF}-\mathrm{OC}$ as a response variable. The cumulative $r^{2}$ values of the significant components, as listed in Table 3, describe the total explanatory power of the model (Carrascal et al., 2009). With the exception of the $\mathrm{CH}$ subsoils, we obtained two significant latent factors (see 


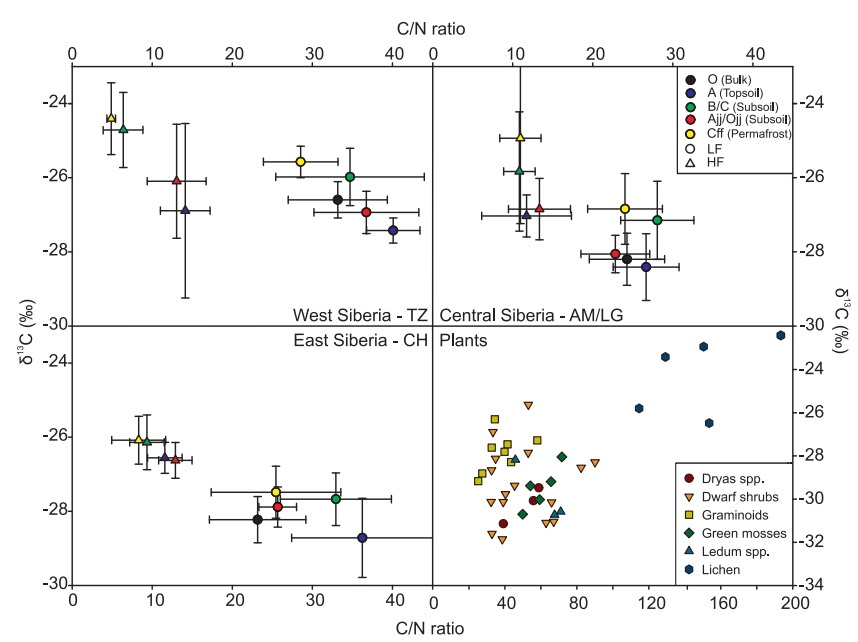

Figure 6. $\delta^{13} \mathrm{C}$ vs. $\mathrm{C} / \mathrm{N}$ ratios for individual soil fractions and the most abundant plants. The values of the soil fractions were grouped according to the genetic soil horizons (mean value \pm SD) and plotted for the different sampling sites. The central Siberian plot incorporated the two sampling sites, AM and LG, where no significant differences were observed for the evaluated parameters. Note the different scale of the plot in the lower right corner.

Sect. 2.4). These factors explained between 42 and $94 \%$ of the HF-OC variance, and the first factor alone explained between 84 and $95 \%$ of the total variance. For this factor, the VIP (variable importance in the projection) values of the individual predictor variables are shown in Fig. 7. Accordingly, organically complexed $\mathrm{Fe}$ and $\mathrm{Al}\left(\mathrm{Fe}_{p}\right.$ and $\left.\mathrm{Al}_{p}\right)$ had the highest explanatory loading for HF-OC in the topsoils and the subducted topsoils. For subsoils and permafrost horizons, the VIP values indicated strong interactions with poorly crystalline $\mathrm{Fe}$ and $\mathrm{Al}$ forms $\left(\mathrm{Fe}_{\mathrm{o}}-\mathrm{Fe}_{p}, \mathrm{Al}_{\mathrm{o}}-\mathrm{Al}_{p}\right)$ in $\mathrm{CH}$ and $\mathrm{LG}$ and a strong affinity to clay-sized minerals in AM and LG. Over all sites and examined soil horizons, well crystalline $\mathrm{Fe}\left(\mathrm{Fe}_{\mathrm{d}}-\mathrm{Fe}_{\mathrm{o}}\right)$ appeared to have either no effect or negative effects on HF-OC.

\section{Discussion}

\subsection{Organic carbon storage in soil horizons linked to cryogenic processes}

The average OC storage of $20.2 \mathrm{~kg} \mathrm{~m}^{-2}$ to $100 \mathrm{~cm}$ soil depth across all sites corresponds well with integrated landscapelevel studies (Table S4). The soil trenches from eastern Siberia described in this study correspond to the tussock tundra and grass tundra classes investigated by Palmtag et al. (2015), which together cover $64 \%$ of the total area. At the Taimyr sites, the soil trenches were representative of wet and dry uplands, which together represent $47 \%$ (AM) and $48 \%$ (LG) of the study areas (Table S4). Hence, the results of our pedon-scaled studies are considered to be representative of

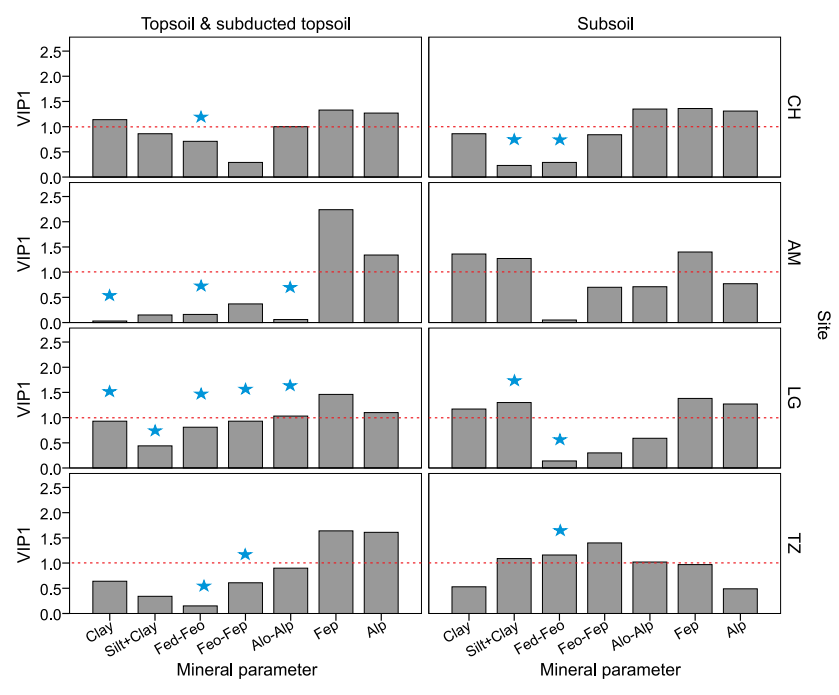

Figure 7. The influence of the PLSR predictor variables on HFOC concentrations plotted as variable importance in the projection (VIP; see Sect. S2) for the first latent factor (see Table 3). Parameters representing the soil mineral phase were used as response variables. Values above the dashed line indicate an above average influence on the response variable. The stars denote negative loadings on a given factor.

the investigated landscape classes across the Siberian Arctic. The OC distribution map (Fig. 8) summarizes the principle findings of this study.

Approximately $81 \%$ of the bulk OC stocks resided in the subsoil. This demonstrates the relevance of deeper soil horizons in cryohydromorphic soils as a long-term C sink and potential source of greenhouse gases (Michaelson et al., 1996). Subduction of topsoil material by cryoturbation, visible as OM-rich pockets, involutions, or tongues in the active layer, was calculated to account for $18 \%$ of the total soil OC and $22 \%$ of the subsoil OC stocks. In their landscape-scale studies, Palmtag et al. (2015) calculated that the landscape-level mean soil OC storage in subducted topsoil materials (including cryoturbations in the permafrost) represented up to $30 \%$ of the total SOC in the first metre. Apart from these most obvious patterns, cryoturbation leads to continuous mixing and rejuvenation of the whole solum, referred to as cryohomogenization (Bockheim et al., 2006; Sokolov et al., 2004). This process was especially relevant for the central and east Siberian sampling sites, and led to high OC content in B and $\mathrm{C}$ horizons (Table S3) and a fairly homogenous mineralogical composition. In contrast, the OC content in western Siberian B, C, and permafrost horizons was up to 11 times lower, reflecting the lack of OM input by cryohomogenization.

In addition to the input via root biomass, cryogenic mass exchange is the principle way for LF materials to enter the deep subsoil, as the studied soils did not exhibit any characteristics of syngenetic soil formation or colluvial deposits. 
Table 3. Results from the PLSR analysis between HF-OC and various mineral parameters. The PLSR factors (latent factors) are given in descending order of importance and the goodness of fit of the model is indicated by regression coefficients for the response variable (cumulative $Y$ variance).

\begin{tabular}{llcccccc}
\hline Site & $\begin{array}{l}\text { Horizon } \\
\text { cluster }\end{array}$ & $\begin{array}{c}\text { Latent } \\
\text { factor }\end{array}$ & $\begin{array}{c}X \\
\text { variance }\end{array}$ & $\begin{array}{c}\text { Cumulative } \\
X \text { variance }\end{array}$ & $\begin{array}{c}Y \\
\text { variance }\end{array}$ & $\begin{array}{c}\text { Cumulative } Y \\
\text { variance }\left(r^{2}\right)\end{array}$ & $\begin{array}{c}\text { Adjusted } \\
r^{2}\end{array}$ \\
\hline $\mathrm{CH}$ & topsoil & 1 & 0.61 & 0.61 & 0.79 & 0.79 & 0.78 \\
& & 2 & 0.12 & 0.73 & 0.10 & 0.88 & 0.88 \\
& subsoil & 1 & 0.44 & 0.44 & 0.62 & 0.62 & 0.61 \\
$\mathrm{AM}$ & topsoil & 1 & 0.23 & 0.23 & 0.74 & 0.74 & 0.73 \\
& & 2 & 0.22 & 0.44 & 0.07 & 0.81 & 0.79 \\
& subsoil & 1 & 0.48 & 0.48 & 0.66 & 0.66 & 0.64 \\
$\mathrm{LG}$ & & 2 & 0.19 & 0.67 & 0.08 & 0.74 & 0.70 \\
& topsoil & 1 & 0.16 & 0.16 & 0.38 & 0.38 & 0.34 \\
& & 2 & 0.31 & 0.47 & 0.05 & 0.42 & 0.36 \\
& subsoil & 1 & 0.56 & 0.56 & 0.79 & 0.79 & 0.76 \\
$\mathrm{TZ}$ & topsoil & 1 & 0.15 & 0.71 & 0.11 & 0.90 & 0.87 \\
& & 2 & 0.26 & 0.46 & 0.79 & 0.79 & 0.78 \\
& subsoil & 1 & 0.33 & 0.33 & 0.75 & 0.75 & 0.93 \\
& & 2 & 0.22 & 0.55 & 0.04 & 0.78 & 0.74 \\
\hline
\end{tabular}

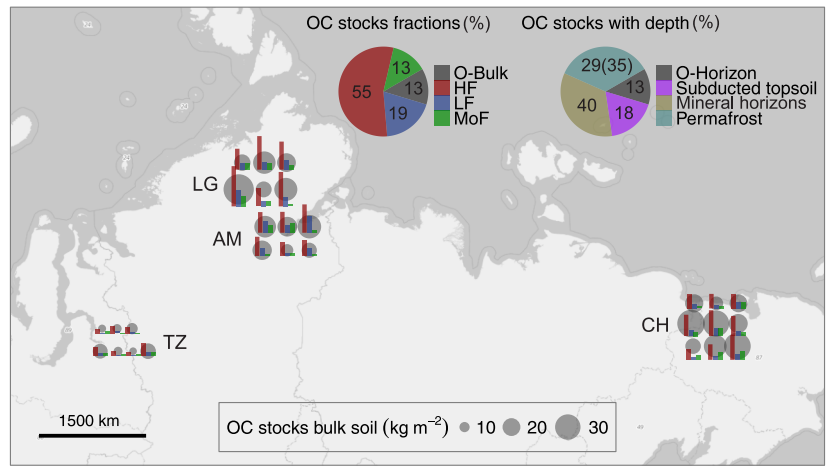

Figure 8. OC distribution map across the Siberian sampling sites. The grey circles show the total OC stock for each profile individually and the coloured bars present the proportion of the specific OM fraction. The pie charts summarize all of the soil profiles. Note that the percentage of permafrost OC summarizes all profiles, while the number in brackets includes only profiles with permafrost within $100 \mathrm{~cm}$ depth.

Subduction of LF by cryoturbation increased the total subsoil OC storage by $22 \%$. In comparison, the amount of LF in temperate environments is often negligible in subsoil and highly vulnerable to disturbances and land management in the topsoil (see review article by Gosling et al., 2013). Cryoturbation is a unique mechanism in permafrost soils to bypass particulate $\mathrm{OM}$ from the access and breakdown by the soil fauna, which is restricted to the well-drained topsoil (Van Vliet-Lanoë, 1998). Thus, coarser plant materials, such as seeds or woody debris (Fig. 5), were distributed across the entire soil profile, including the permafrost, where the subsoil LF decomposition is restricted to biochemically medi- ated microbial processes. Therefore, the particle size of LF materials in the subsoil is expected to depend on the time of subduction and the stage of detritus formation.

Besides cryoturbation, the vertical transfer of dissolved and colloidal organic compounds, often not considered in permafrost soils, also appears to be important with regard to OC storage. Preferred OC accumulation was observed in the transient layer of several profiles (profiles CH D-I, AM A-C, LG D; Fig. S7). Within these profiles, a sharp increase in HF-OC (from $8.2 \pm 4.0$ to $14.4 \pm 10.0 \mathrm{~g} \mathrm{~kg}^{-1}$ ) and MoF$\mathrm{OC}$ (from $1.7 \pm 1.8$ to $3.6 \pm 4.8 \mathrm{~g} \mathrm{~kg}^{-1}$ ) was observed in the upper BCgjj and Cgjj horizons towards the Cgjj and Cff horizons of the transient layer. On the basis of our profile maps, we calculated the area of the accumulation zone and the difference in MoF-OC and HF-OC between the upper subsoil horizons and the transient layer. This difference accounted for an increase in OC storage of 0.2 to $3.7 \mathrm{~kg} \mathrm{~m}^{-2}$, which translates into $1-12 \%$ of the respective bulk soil OC stock. Enrichment of well-decomposed, humic-rich OM in the transient layer has also been reported elsewhere (Gundelwein et al., 2007; Mergelov and Targulian, 2011; Ostroumov et al., 2001). Mergelov and Targulian (2011) explained this enrichment by the concept of "cryogenic retenization", denoting the vertical migration and subsequent precipitation of mobile $\mathrm{OM}$ during ice segregation along freezing gradients. Because the LF can only be transferred by cryoturbation, only the pools of $\mathrm{HF}$ and MoF are affected by this process.

By considering all soil horizons with evidence of cryogenic processes (including BCgjj and Cgjj horizons), an average of $54 \%$ of the total OC storage can be attributed to re-allocation by cryogenesis in the active layer. Bockheim (2007) published an almost equal number $(55 \%)$ for 
21 pedons in Alaska, which was calculated using a similar approach. Cryogenic processes as a mechanism to sequester OC are often not incorporated into discussions about subsoil OM (e.g. Rumpel and Kögel-Knabner, 2011), but the global relevance of this process cannot be neglected. Gelisols cover $9.1 \%$ of the global ice-free land area (USDA, 1999) and Turbels account for $61 \%$ of the Gelisol area (Hugelius et al., 2014). The latter calculated the amount of soil OC in circumpolar Turbels to be $207 \mathrm{Pg}$. Assuming that the first metre of the global soils store $1324 \mathrm{Pg}$ of OC (Köchy et al., 2015), cryoturbated permafrost soils account for approximately $15 \%$ of this global value. Based on the $54 \%$ re-allocation of OC by cryogenesis, approximately $8 \%$ or $110 \mathrm{Pg}$ of the global soil OC pool within the first metre can be attributed to the redistribution by cryogenic processes. This proportion will increase when cryoturbated materials within the permafrost and $>1 \mathrm{~m}$ are taken into account (Harden et al., 2012).

\subsection{Transformation of organic matter in the cryoturbated soils}

We used $\mathrm{C} / \mathrm{N}$ values and $\delta^{13} \mathrm{C}$ ratios together with density fractionation to assess the $\mathrm{OM}$ transformation within the cryoturbated soils. Smaller C / N ratios and more positive $\delta^{13} \mathrm{C}$ values of OM with soil depth (Fig. 4) are both indicative of consecutive microbial transformation from organic topsoil towards permafrost horizons. In this study, OM in deep B and $\mathrm{C}$ horizons as well as in the upper permafrost underwent the strongest transformation. This is in contrast to the findings of $\mathrm{Xu}$ et al. (2009) from sites in Alaska and might indicate temporarily greater thawing depths and/or microbial OM transformation at subzero temperatures (Gittel et al., 2014; Hobbie et al., 2000). However, the subducted topsoil material did not fit with this pattern. The transformation proxies of the bulk soil OM did not resemble those of the surrounding subsoil, but rather those of the respective topsoil horizons. In addition, when considering the HF, mineral-associated OM did not indicate alteration in the subducted topsoils compared to the A horizons. The LF in the subducted topsoil material, however, was significantly enriched in ${ }^{13} \mathrm{C}$ and had smaller $\mathrm{C} / \mathrm{N}$ ratios than that of the topsoil. This pattern can likely be attributed to the availability of large amounts of unprotected particulate OM over a longer time period for microbial decomposition. According to Gentsch et al. (2015), the LF ${ }^{14} \mathrm{C}$ signals decreased from modern values in the topsoil to 81 and $84 \mathrm{pMC}$ ( 1300 to 1600 years BP) in subducted topsoil. The reduced bioavailability during incubation experiments indicates depletion of energy-rich plant material.

Narrow $\mathrm{C} / \mathrm{N}$ ratios in the HF relative to LF indicate a larger proportion of microbial products (Christensen, 2001) and the $\mathrm{HF}$ as principle source of $\mathrm{N}$ in the soil (Khanna et al., 2001). The strong decline in the $\mathrm{C} / \mathrm{N}$ values of the HF from the topsoil towards the permafrost (Fig. 6) mirrors the increasing contribution of microbial residues to mineralassociated $\mathrm{OM}$ at greater soil depth. Very narrow HF C / N ratios in the subsoil at $\mathrm{TZ}(5 \pm 1)$ and $\mathrm{CH}(8 \pm 4)$ likely reflect the fixation of $\mathrm{NH}_{4}^{+}$in the interlayer of expandable $2: 1$ clay minerals (Dixon and Schulze, 2002). However, considering the generally low concentrations of mineral $\mathrm{N}$ in the soils $(<2 \%$; data not shown) and the loss thereof during the density fractionation, the proportion of mineral $\mathrm{N}$ to the TN in the whole soil HF appears to be negligible. For $\mathrm{LF}-\mathrm{OM}$, higher $\mathrm{C} / \mathrm{N}$ ratios were found in the topsoil from $\mathrm{TZ}(40 \pm 3)$ and $\mathrm{CH}(38 \pm 8)$ relative to $\mathrm{AM}$ and $\mathrm{LG}$ soils $(26 \pm 4)$, reflecting signals from plant sources with wider $\mathrm{C} / \mathrm{N}$ ratios, such as mosses or lichen (Fig. 6). Although the $\mathrm{C} / \mathrm{N}$ ratio of the plant input was wider at $\mathrm{TZ}$ and $\mathrm{CH}$ than at the AM and LG sites, the ratio became narrower with depth at the former, suggesting stronger decomposition, and for TZ less active cryogenic processes (discussed above). The generally less negative $\delta^{13} \mathrm{C}$ values of $\mathrm{OM}$ at $\mathrm{TZ}$ sites were, however, the result of less strong isotope discrimination by the plant sources instead of an advanced stage of decomposition. This can be linked to environmental forces (e.g. the less pronounced continentality; see Supplement) influencing water-nutrient use efficiency and water vapour pressure, which in turn affect photosynthetic discrimination (Bowling et al., 2002; Dawson et al., 2002).

Overall, the bulk and fraction-related OM showed a strong microbial transformation with soil depth. The subducted topsoil material was an exception, however, as only the LF appeared to be more decomposed than the respective fraction in the topsoil. For the CH sample subset, Gittel et al. (2014) showed a relatively high abundance of bacteria (especially actinobacteria) in subducted topsoil materials, but a similar, low abundance of fungi as in the surrounding subsoil. Differences in the microbial community composition, therefore, cannot explain the preferential degradation of LF material in the cryoturbated pockets, as LF materials with high $\mathrm{C} / \mathrm{N}$ are favoured by the fungal community (Six et al., 2006). Concurrently, Schnecker et al. (2014) suggested low adaption of the microbial community to the available substrate in subducted topsoils. These findings imply that subsoil OM decomposition in cryohydromorphic soils largely depends on the adaption of the microbial community composition to microenvironments (abiotic conditions) instead of the availability of OC sources. Consequently, the retarded OM decomposition in cryoturbated permafrost soils may not be a matter of substrate availability (Kaiser et al., 2007) nor substrate quality (Schnecker et al., 2014; Xu et al., 2009), but instead may be restricted by abiotic conditions (Harden et al., 2012) and nitrogen limitation of enzyme production (Wild et al., 2014).

\subsection{Potentially solubilizable organic matter}

The concentrations of $\mathrm{K}_{2} \mathrm{SO}_{4}$-extractable dissolved $\mathrm{OC}$ (DOC) from fresh soil of the $\mathrm{CH}$ and Taimyr soils ranged from $5.2 \mathrm{mg} \mathrm{g}^{-1}$ in organic topsoil to $0.01 \mathrm{mg} \mathrm{g}^{-1}$ in subsoil, representing approximately 2.3 to $0.04 \%$ of the total OC (data not shown). Similar values were reported from water 
extracts by Dutta et al. (2006) for Kolyma lowland soils. In contrast, the DOC concentrations measured in the MoF were remarkably larger and accounted from 0.3 to $75 \%$ (on average $13 \%$ ) of the total OC content (Table S3). The maximum proportion of the initial OC release $(>30 \%)$ was found in $\mathrm{B} / \mathrm{C}$ and Cff horizons from TZ and LG where total OC content was small (1-8 $\mathrm{mg} \mathrm{g}^{-1}$ soil) and the HF strongly dominated the OC storage. As shown in Fig. S1, approximately $80 \%$ of the MoF-OC was derived from the HF as a result of the SPT-induced desorption of OM outlined by Crow et al. (2007) and Kaiser and Guggenberger (2007). However, the release of OM by SPT was found to be small in temperate, arable, and high-latitude forest soils (e.g. John et al., 2005; Kaiser and Guggenberger, 2007; Kane et al., 2005). The data from this study, however, point towards a relatively large pool of mineral-associated OM, which is retained in weaker, chemically exchangeable bindings. The high soil $\mathrm{pH}$ in the subsoil, usually $\mathrm{pH}>6$ and up to $\mathrm{pH} 9$ in permafrost horizons, might directly affect the binding strengths. Maximum $\mathrm{OM}$ sorption to sesquioxides occurs at $\mathrm{pH} 4-5$, while $\mathrm{OM}$ is most soluble at $\mathrm{pH}$ 6-8 due to the increasing deprotonation of OM and the decreasing positive charge on metal oxide surfaces (Andersson et al., 2000; Whittinghill and Hobbie, 2012), thus causing an overall increase in OM mobilization at higher $\mathrm{pH}$ (Kalbitz et al., 2000). The anaerobic conditions in the subsoil may promote the OM release, because anaerobic decomposition of OM leaves a high proportion of water-soluble intermediate metabolites behind (Kalbitz et al., 2000), and the reductive dissolution of iron oxides leads to the mobilization of the formerly sorbed OM (Fiedler and Kalbitz, 2003; Hagedorn et al., 2000). Furthermore, frequent freezing-thawing cycles have been found to increase dissolved OM loads by disrupting microbial tissue and cell lysis (DeLuca et al., 1992). As water-soluble OM is the most bioavailable fraction (Marschner and Kalbitz, 2003), the MoF includes a potentially vulnerable soil OM pool.

The mobility of soluble compounds (including metal ions and dissolved $\mathrm{OM}$ ) in the annual thawing zone is controlled by the formation of segregation ice. During crystal growth, the soluble compounds remain in the pore solution and increase electrolyte concentrations (Ostroumov et al., 2001). Zones of concentrated pore solution favour colloid flocculation and the formation of metal-loaded organic precipitates (Ostroumov, 2004; Van Vliet-Lanoë, 1998). Coprecipitation has been postulated as an important mechanism for OM preservation in soils (Gentsch et al., 2015; Kalbitz and Kaiser, 2008; Scheel et al., 2007), and on this basis, freeze and thaw cycles would not only increase the production of DOC but also stimulate the formation of mineralorganic associations.

\subsection{Mineral controls on organic matter storage}

Approximately $55 \%$ of the total OC in the first soil metre and $63 \%$ of the OC within subsoil horizons was associated with the mineral phase. Soil OM that interacts with reactive minerals is supposed to be less available for microbial decomposition, thus contributing to the "protected" or "stabilized" OM pool (Schmidt et al., 2011). The extent of protection thereby depends on the mineralogical assemblage and the soil environmental conditions (Baldock and Skjemstad, 2000).

The PLSR analyses (Fig. 7) highlight the site-specific significance of certain mineral phases that act as potential binding partners for OM. Well crystalline iron oxides $\left(\mathrm{Fe}_{\mathrm{d}}-\mathrm{Fe}_{\mathrm{o}}\right)$, generally low in abundance, have no or a negative effect on HF-OC variability across all sites. The significance of well crystalline minerals for the stabilization of OM in mineralorganic associations has been addressed in several studies on temperate (Eusterhues et al., 2005; Mikutta et al., 2007) and tropical soils (Mikutta et al., 2009; Torn et al., 1997) and is generally considered low. Poorly crystalline $\mathrm{Fe}$ and $\mathrm{Al}$ phases $\left(\mathrm{Fe}_{\mathrm{o}}-\mathrm{Fe}_{p}, \mathrm{Al}_{\mathrm{o}}-\mathrm{Al}_{p}\right)$ are more important at $\mathrm{CH}$ and $\mathrm{TZ}$, where weathering was found to be strongest (see Supplement Sect. S4).

Clay-sized minerals have a strong influence on HF-OC in the subsoils at sites dominated by highly reactive smectite clays (AM, LG). This finding is in agreement with Six et al. (2002), who showed that stabilization of OC is related to the type of clay minerals $(2: 1$ or $1: 1)$ present in soil. The authors suggest that the stronger adsorption capacity of $2: 1$ clays is based on differences in CEC and surface area.

The PLSR further identified organically complexed Fe and Al $\left(\mathrm{Fe}_{p}, \mathrm{Al}_{p}\right)$ as an overwhelming factor explaining the variations in HF-OC concentrations across all study sites (Fig. 7). Sorption of $\mathrm{OM}$ to the surfaces of phyllosilicate clays, partly complexed with $\mathrm{Fe}$ and $\mathrm{Al}$, may reduce their specific surface area and "glue" them together under formation of ternary complexes (OM-Fe/Al-oxi(hydroxy)desclay complexes) complexes (Wagai and Mayer, 2007). The interplay between $\mathrm{OM}$, clay minerals, and less polymeric $\mathrm{Fe}$ and $\mathrm{Al}$ species may partly reduce the explanatory power of the clay-OM relation alone during statistical analyses. In addition to the formation of ternary complexes, the presence of $\mathrm{Fe}_{p}$ and $\mathrm{Al}_{p}$ in the HF may also result from co-precipitation reactions between $\mathrm{OM}$ and dissolved $\mathrm{Fe}$ and $\mathrm{Al}$ (Scheel et al., 2007; Schwertmann et al., 2005). When plotting the molar concentration of $\mathrm{HF}-\mathrm{OC}$ versus those of $\mathrm{Fe}_{p}+\mathrm{Al}_{p}$, linear relations were observed with different regression slopes for different sites (Fig. S5; $r=0.63$ to $0.97 ; p<0.001$ ). The slopes show molar metal / $\mathrm{C}$ ratios of 0.02 for $\mathrm{CH}$ and $\mathrm{TZ}$ sites and $<0.01$ for the Taimyr sites. These strong relationships suggest a proportional increase in Fe / Al-OM associations with the amount of OC present in the soil. Several studies have reported that the precipitation of $\mathrm{OM}$ with hydrolysed $\mathrm{Al}$ and Fe species already begins at low metal / $\mathrm{C}$ ratios of $<0.05$ (Nierop et al., 2002; Scheel et al., 2007). These findings sup- 
port our previous conclusion - that, besides clay-organic interactions, co-precipitation of $\mathrm{OM}$ with $\mathrm{Fe}$ and $\mathrm{Al}$ is another important process in cryohydromorphic soils (Gentsch et al., 2015).

Overall, it appeared difficult to differentiate distinct mechanisms of mineral-organic interactions for cryohydromorphic soils of the Siberian Arctic. Statistical evidence was found for (i) complexation of OM with metal cations, (ii) formation of $\mathrm{Fe} / \mathrm{Al}$ co-precipitates, and (iii) sorption of $\mathrm{OM}$ to clay minerals and poorly crystalline $\mathrm{Fe}$ and $\mathrm{Al}$ phases. Whether the formation of mineral-organic associations may retard the decomposition of OM depends, however, on the stability of these complexes (Mikutta et al., 2007). Reductive dissolution of iron oxides may liberate the attached OM (Fiedler and Kalbitz, 2003; Knorr, 2013). The strongest mineral-organic binding, such as ligand exchange, occurs in acid soils (Von Lützow et al., 2006), whereas weaker outersphere complexes prevail in the neutral to alkaline conditions that dominate the subsoil of northern Siberia. In an artificial cryoturbation experiment, Klaminder et al. (2013) found that mixing of humus into mineral soil from cryoturbated soils primed heterotrophic respiration, possibly as result of contact with mineral surfaces. Gentsch et al. (2015) performed incubation experiments over 90 days using bulk soils, HF, and LF materials from the $\mathrm{CH}$ sites. In this study, only up to $\sim 3 \%$ of the initial mineral-associated OC was respired. Jagadamma et al. (2013) reported slightly higher native $\mathrm{OC}$ mineralization of mineral-associated $\mathrm{OM}$ from a Typic Aquiturbel relative to non-permafrost soils from various environments, and no significant difference between the HF and LF was observed. Although the stability of mineralorganic associations as protecting agents against microbial OM degradation appears uncertain so far and warrants further research, our results suggest that soil minerals in cryoturbated permafrost soils are crucial factors facilitating high OC stocks in the subsoil.

\section{Conclusions}

This study investigated 28 cryoturbated soils on poorly drained, silty-loamy parent material with relatively flat topography in a gradient from western to eastern Siberia. All soils belonged to the Aquiturbel great group. Differences in physico-chemical properties and processes depend on the heterogeneity of the parent material, the annual thawing depth, and the occurrence of cryogenic processes. Based on the average storage of $20.2 \pm 8.0 \mathrm{~kg} \mathrm{OC} \mathrm{m}^{-2}, 54 \%$ was redistributed by cryogenic processes as principle drivers for the high subsoil OC stocks of $16.4 \pm 8.1 \mathrm{~kg} \mathrm{OC} \mathrm{m}^{-2}$. The vast majority of the subsoil OC was associated with minerals (HF: $10.3 \pm 4.9 \mathrm{~kg} \mathrm{OC} \mathrm{m}^{-2}$ ) and dominated by microbially resynthesized products. The size of this pool depends on the yield of dissolved compounds delivered by microbial transformation, migration along freezing gradients, and the mineral assemblage. Substantial microbial OM transformation in the subsoil was indicated by low $\mathrm{C} / \mathrm{N}$ ratios and high $\delta^{13} \mathrm{C}$ values, despite the unfavourable abiotic conditions (i.e. water saturation, anaerobiosis, low temperatures). Under current soil conditions, mineral-organic associations emerge from complexation of $\mathrm{OM}$ with metal cations, the formation of $\mathrm{Fe} / \mathrm{Al}-\mathrm{OM}$ co-precipitates, as well as sorption of $\mathrm{OM}$ to poorly crystalline $\mathrm{Fe}$ and $\mathrm{Al}$ surfaces and clay minerals. In the absence of segregated ground-ice bodies, future climate scenarios predict increases in active layer depth and deep drainage (IPCC, 2013; Schaefer et al., 2011; Sushama et al., 2007), likely resulting in dryer and more oxic soil conditions. Drainage and oxygen availability give rise to proceeding soil development (acidification) as well as mineral alteration under the release of $\mathrm{Fe}$ and $\mathrm{Al}$ to the soil solution, formation of iron and aluminium oxides, reduction of exchangeable basic cations, and clay mineral transformation. This, in turn, may increase the relevance of mineral-organic associations to mitigate the permafrost carbon feedback to climate change by reducing the microbial excess to the OC source. However, further studies are needed to understand the specific mechanisms that cause the enrichment of $\mathrm{OC}$ on mineral surfaces (adsorption versus co-precipitation reactions) and the role of minerals in permafrost soils as a substantial protection factor for OM.

\section{The Supplement related to this article is available online at doi:10.5194/bg-12-4525-2015-supplement.}

Acknowledgements. Financial support was provided by the German Federal Ministry of Education and Research (03F0616A) within the ERANET EUROPOLAR project CryoCARB. N. Gentsch appreciates financial support by the Evangelisches Studienwerk Villigst, and O. Shibistova and G. Guggenberger acknowledge funding by the Russian Ministry of Education and Science (no. 14.B25.31.0031). Contributions from P. Kuhry, G. Hugelius, and J. Palmtag were supported by the Swedish Research Council within the ERANET EUROPOLAR project CryoCARB. Special thanks go to Claudia Borchers for in-depth statistical discussions, Charles Tarnocai for helpful comments on soil descriptions, and all members of the CryoCARB project for the incredible team spirit. We acknowledge support from the Deutsche Forschungsgemeinschaft and the Open Access Publishing Fund of the Leibniz Universität Hannover.

Edited by: Y. Kuzyako

\section{References}

Andersson, S., Nilsson, S. I., and Saetre, P.: Leaching of dissolved organic carbon (DOC) and dissolved organic nitrogen (DON) in mor humus as affected by temperature and $\mathrm{pH}$, Soil Biol. Biochem., 32, 1-10, 2000. 
Baldock, J. A. and Skjemstad, J. O.: Role of the soil matrix and minerals in protecting natural organic materials against biological attack, Org. Geochem., 31, 697-710, 2000.

Bockheim, J. G.: Importance of Cryoturbation in Redistributing Organic Carbon in Permafrost-Affected Soils, Soil Sci. Soc. Am. J., 71, 1335-1342, 2007.

Bockheim, J. G. and Tarnocai, C.: Recognition of cryoturbation for classifying permafrost-affected soils, Geoderma, 81, 281-293, 1998.

Bockheim, J. G., Tarnocai, C., Kimble, J. M., and Smith, C. A. S.: The Concept of Gelic Materials in the New Gelisol Order for Permafrost-Affected Soils, Soil Sci., 162, 927-939, 1997.

Bockheim, J. G., Mazhitova, G., Kimble, J. M., and Tarnocai, C.: Controversies on the genesis and classification of permafrostaffected soils, Geoderma, 137, 33-39, 2006.

Bowling, D. R., McDowell, N. G., Bond, B. J., Law, B. E., and Ehleringer, J. R.: ${ }^{13} \mathrm{C}$ content of ecosystem respiration is linked to precipitation and vapor pressure deficit, Oecologia, 131, 113124, 2002.

Carrascal, L. M., Galván, I., and Gordo, O.: Partial least squares regression as an alternative to current regression methods used in ecology, Oikos, 118, 681-690, doi:10.1111/j.16000706.2008.16881.x, 2009.

Carter, M. and Gregorich, E. (Eds.): Soil Sampling and Methods of Analysis, Second Edn., edited by: Carter, M. R. and Gregorrich E. G., CRC Press, Boca Raton, Florida, USA, 2008.

Christensen, B. T.: Physical fractionation of soil and structural and functional complexity in organic matter turnover, Eur. J. Soil Sci., 52, 345-353, 2001.

Cornell, R. M. and Schwertmann, U.: The iron oxides: Structure, Properties, Reactions, Occurrences and Uses, WILAY-VCH, Weinheim, 2003.

Crow, S., Swanston, C., Lajtha, K., Brooks, J., and Keirstead, H.: Density fractionation of forest soils: methodological questions and interpretation of incubation results and turnover time in an ecosystem context, Biogeochemistry, 85, 69-90, 2007.

Davidson, E. A. and Janssens, I. A.: Temperature sensitivity of soil carbon decomposition and feedbacks to climate change, Nature, 440, 165-173, 2006.

Dawson, T. E., Mambelli, S., Plamboeck, A. H., Templer, P. H., and Tu, K. P.: Stable Isotopes in Plant Ecology, Annu. Rev. Ecol. Syst., 33, 507-559, 2002.

DeConto, R. M., Galeotti, S., Pagani, M., Tracy, D., Schaefer, K., Zhang, T., Pollard, D., and Beerling, D. J.: Past extreme warming events linked to massive carbon release from thawing permafrost, Nature, 484, 87-91, 2012.

DeLuca, T. H., Keeney, D. R., and McCarty, G. W.: Effect of freezethaw events on mineralization of soil nitrogen, Biol. Fert. Soils, 14, 116-120, doi:10.1007/BF00336260, 1992.

DIN ISO 11277: Soil quality - Determination of particle size distribution in mineral soil material - Method by sieving and sedimentation, Beuth, Berlin, 2002.

Dixon, J. B. and Schulze, D. G.: Soil mineralogy with environmental applications, Soil Science Society of America Inc., Madison, WI, 2002.

Dutta, K., Schuur, E. A. G., Neff, J. C., and Zimov, S. A.: Potential carbon release from permafrost soils of Northeastern Siberia, Glob. Change Biol., 12, 2336-2351, 2006.
Eusterhues, K., Rumpel, C., and Kögel-Knabner, I.: Organomineral associations in sandy acid forest soils: importance of specific surface area, iron oxides and micropores, Eur. J. Soil Sci., 56, 753-763, 2005.

Eusterhues, K., Wagner, F. E., Häusler, W., Hanzlik, M., Knicker, H., Totsche, K. U., Kögel-Knabner, I., and Schwertmann, U.: Characterization of ferrihydrite-soil organic matter coprecipitates by X-ray Diffraction and Mössbauer Spectroscopy, Environ. Sci. Technol., 42, 7891-7897, 2008.

Fiedler, S. and Kalbitz, K.: Concentrations and properties of dissolved organic matter in forest soils as affected by the redox regime, Soil Sci., 168, 793-801, 2003.

Fountain, A. G., Campbell, J. L., Schuur, E. A. G., Stammerjohn, S. E., Williams, M. W., and Ducklow, H. W.: The Disappearing Cryosphere: Impacts and Ecosystem Responses to Rapid Cryosphere Loss, Bioscience, 62, 405-415, 2012.

French, H. and Shur, Y.: The principles of cryostratigraphy, EarthSci. Rev., 101, 190-206, 2010.

Gentsch, N., Mikutta, R., Shibistova, O., Wild, B., Schnecker, J., Richter, A., Urich, T., Santruckova, H., Barta, J., Gittel, A., Lashchinskiy, N., Müller, C., Fuß, R., and Guggenberger, G.: Dynamics of particulate and mineral-associated organic matter in Arctic permafrost soils, Lower Kolyma Region, Russia, Eur. J. Soil Sci., 66, 722-734, doi:10.1111/ejss.12269, 2015.

Gittel, A., Bárta, J., Kohoutová, I., Mikutta, R., Owens, S., Gilbert, J., Schnecker, J., Wild, B., Hannisdal, B., Maerz, J., Lashchinskiy, N., Čapek, P., Šantrůčková, H., Gentsch, N., Shibistova, O., Guggenberger, G., Richter, A., Torsvik, V. L., Schleper, C., and Urich, T.: Distinct microbial communities associated with buried soils in the Siberian tundra, ISME J., 8, 841-853, 2014.

Golchin, A., Oades, J., Skjemstad, J., and Clarke, P.: Study of free and occluded particulate organic matter in soils by solid state ${ }^{13} \mathrm{C}$ Cp/MAS NMR spectroscopy and scanning electron microscopy, Soil Res., 32, 285-309, 1994.

Gosling, P., Parsons, N., and Bending, G. D.: What are the primary factors controlling the light fraction and particulate soil organic matter content of agricultural soils?, Biol. Fert. Soils, 49, 10011014, 2013.

Gundelwein, A., Müller-Lupp, T., Sommerkorn, M., Haupt, E. T. K., Pfeiffer, E.-M., and Wiechmann, H.: Carbon in tundra soils in the Lake Labaz region of arctic Siberia, Eur. J. Soil Sci., 58, 1164-1174, 2007.

Hagedorn, F., Kaiser, K., Feyen, H., and Schleppi, P.: Effects of Redox Conditions and Flow Processes on the Mobility of Dissolved Organic Carbon and Nitrogen in a Forest Soil, J. Environ. Qual., 29, 288-297, doi:10.2134/jeq2000.00472425002900010036x, 2000.

Harden, J. W., Koven, C. D., Ping, C.-L., Hugelius, G., David McGuire, A., Camill, P., Jorgenson, T., Kuhry, P., Michaelson, G. J., O’Donnell, J. A., Schuur, E. A. G., Tarnocai, C., Johnson, K., and Grosse, G.: Field information links permafrost carbon to physical vulnerabilities of thawing, Geophys. Res. Lett., 39, L15704, doi:10.1029/2012GL051958, 2012.

Harris, D., Horwáth, W. R., and van Kessel, C.: Acid fumigation of soils to remove carbonates prior to total organic carbon or CARBON-13 isotopic analysis, Soil Sci. Soc. Am. J., 65, $1853-$ 1856, 2001. 
Hobbie, S. E., Schimel, J. P., Trumbore, S. A., and Randerson, J. R.: Controls over carbon storage and turnover in high-latitute soils, Glob. Change Biol., 6, 196-210, 2000.

Höfle, S., Rethemeyer, J., Mueller, C. W., and John, S.: Organic matter composition and stabilization in a polygonal tundra soil of the Lena Delta, Biogeosciences, 10, 3145-3158, doi:10.5194/bg10-3145-2013, 2013.

Hugelius, G., Kuhry, P., Tarnocai, C., and Virtanen, T.: Soil organic carbon pools in a periglacial landscape: a case study from the central Canadian Arctic, Permafrost Periglac., 21, 16-29, doi:10.1002/ppp.677, 2010.

Hugelius, G., Strauss, J., Zubrzycki, S., Harden, J. W., Schuur, E. A. G., Ping, C.-L., Schirrmeister, L., Grosse, G., Michaelson, G. J., Koven, C. D., O'Donnell, J. A., Elberling, B., Mishra, U., Camill, P., Yu, Z., Palmtag, J., and Kuhry, P.: Estimated stocks of circumpolar permafrost carbon with quantified uncertainty ranges and identified data gaps, Biogeosciences, 11, 6573-6593, doi:10.5194/bg-11-6573-2014, 2014.

Hut, G.: Consultants' group meeting on stable isotope reference samples for geochemical and hydrological investigations, available at: http://inis.iaea.org/Search/search.aspx?orig_q=RN: 18075746 (last access: 22 August 2014), 1987.

IPCC: Climate Change 2013: The Physical Science Basis. Contribution of Working Group I to the Fifth Assessment Report of the Intergovernmental Panel on Climate Change, edited by: Stocker, T. F., Qin, D., Plattner, G.-K., Tignor, M., Allen, S. K., Boschung, J., Naulas, A., Xia, Y., Bex, V., and Midgley, P. M., Cambridge University Press, Cambridge, UK and New York, NY, USA, 2013.

Jagadamma, S., Steinweg, J. M., Mayes, M. A., Wang, G., and Post, W. M.: Decomposition of added and native organic carbon from physically separated fractions of diverse soils, Biol. Fert. Soils, 50, 613-621, 2013.

John, B., Yamashita, T., Ludwig, B., and Flessa, H.: Storage of organic carbon in aggregate and density fractions of silty soils under different types of land use, Geoderma, 128, 63-79, 2005.

Kaiser, C., Meyer, H., Biasi, C., Rusalimova, O., Barsukov, P., and Richter, A.: Conservation of soil organic matter through cryoturbation in arctic soils in Siberia, J. Geophys. Res., 112, 9-17, 2007.

Kaiser, K. and Guggenberger, G.: Distribution of hydrous aluminium and iron over density fractions depends on organic matter load and ultrasonic dispersion, Geoderma, 140, 140-146, 2007.

Kalbitz, K. and Kaiser, K.: Contribution of dissolved organic matter to carbon storage in forest mineral soils, J. Plant Nutr. Soil Sc., 171, 52-60, doi:10.1002/jpln.200700043, 2008.

Kalbitz, K., Solinger, S., Park, J.-H., Michalzik, B., and Matzner, E.: Controls on the Dynamics of Dissolved Organic Matter in Soils: A Review, Soil Sci., 165, 277-304, 2000.

Kane, E. S., Valentine, D. W., Schuur, E. A. G., and Dutta, K.: Soil carbon stabilization along climate and stand productivity gradients in black spruce forests of interior Alaska., Can. J. Forest Res., 35, 2118-2129, 2005.

Khanna, P. K., Ludwig, B., Bauhus, J., and O'Hara, C.: Assessment and Significance of Labile Organic C Pools in Forest Soils, in: Assessment Methods for Soil Carbon, edited by: Lal, R., Kimble, J. M., Follett, R. F., and Stewart, B. A., CCR Press LLC, Boca Raton, 167-185, 2001.
Klaminder, J., Giesler, R., and Makoto, K.: Physical mixing between humus and mineral matter found in cryoturbated soils increases short-term heterotrophic respiration rates, Soil Biol. Biochem., 57, 922-924, 2013.

Knorr, K.-H.: DOC-dynamics in a small headwater catchment as driven by redox fluctuations and hydrological flow paths - are DOC exports mediated by iron reduction/oxidation cycles?, Biogeosciences, 10, 891-904, doi:10.5194/bg-10-891-2013, 2013.

Köchy, M., Hiederer, R., and Freibauer, A.: Global distribution of soil organic carbon - Part 1: Masses and frequency distributions of SOC stocks for the tropics, permafrost regions, wetlands, and the world, SOIL, 1, 351-365, doi:10.5194/soil-1-351-2015, 2015.

Kögel-Knabner, I., Guggenberger, G., Kleber, M., Kandeler, E., Kalbitz, K., Scheu, S., Eusterhues, K., and Leinweber, P.: Organo-mineral associations in temperate soils: Integrating biology, mineralogy, and organic matter chemistry, Z. Pflanzenernaehr. Bodenk., 171, 61-82, 2008.

Koven, C. D., Ringeval, B., Friedlingstein, P., Ciais, P., Cadule, P., Khvorostyanov, D., Krinner, G., and Tarnocai, C.: Permafrost carbon-climate feedbacks accelerate global warming, Proc. Nat. Acad. Sci. USA, 108, 14769-14774, 2011.

Kuhry, P., Dorrepaal, E., Hugelius, G., Schuur, E. A. G., and Tarnocai, C.: Potential remobilization of belowground permafrost carbon under future global warming, Permafrost Periglac., 21, 208-214, doi:10.1002/ppp.684, 2010.

Lutwick, L. and Dormaar, J.: Fe status of Brunisolic and related soil profiles, Can. J. Soil Sci., 53, 185-197, 1973.

Marschner, B. and Kalbitz, K.: Controls of bioavailability and biodegradability of dissolved organic matter in soils, Geoderma, 113, 211-235, 2003.

McKeague, J. A. and Day, J. H.: Dithionite- and Oxalate-extractable $\mathrm{Fe}$ and $\mathrm{Al}$ as aids in differentiating various classes of soils, Can. J. Soil Sci., 46, 13-22, 1966.

Mergelov, N. and Targulian, V.: Accumulation of organic matter in the mineral layers of permafrost-affected soils of coastal lowlands in East Siberia, Eurasian Soil Sci., 44, 249-260, 2011.

Michaelson, G. J., Ping, C., and Kimble, J. M.: Effects of Soil Morphological and Physical Properties on Estimation of Carbon Storage in Arctic Soils, in: Assessment Methods for Soil Carbon, edited by: Lal, R., Kimble, J. M., Follett, R. F., and Stewart, B. A., Lewis Publishers, London, New York, Washington DC, 339 347, 2001.

Michaelson, G. J., Ping, C. L., and Kimble, J. M.: Carbon Storage and Distribution in Tundra Soils of Arctic Alaska, U.S.A., Arct. Antarct. Alp. Res., 28, 414-424, 1996.

Mikutta, R., Mikutta, C., Kalbitz, K., Scheel, T., Kaiser, K., and Jahn, R.: Biodegradation of forest floor organic matter bound to minerals via different binding mechanisms, Geochim. Cosmochim. Ac., 71, 2569-2590, doi:10.1016/j.gca.2007.03.002, 2007.

Mikutta, R., Schaumann, G. E., Gildemeister, D., Bonneville, S., Kramer, M. G., Chorover, J., Chadwick, O. A., and Guggenberger, G.: Biogeochemistry of mineral-organic associations across a long-term mineralogical soil gradient (0.3-4100 kyr), Hawaiian Islands, Geochim. Cosmochim. Ac., 73, 2034-2060, doi:10.1016/j.gca.2008.12.028, 2009. 
Moore, D. M. and Reynolds, R. C.: X-Ray Diffraction and Identification and Analysis of Clay Minerals, 2nd Edn., Oxford University Press, Oxford, New York, 1997.

Nierop, K. G. J. J., Jansen, B., and Verstraten, J. M.: Dissolved organic matter, aluminium and iron interactions: precipitation induced by metal/carbon ratio, $\mathrm{pH}$ and competition, Sci. Total Environ., 300, 201-211, doi:10.1016/S0048-9697(02)00254-1, 2002

Ostroumov, V.: Physico-Chemical Processes in Cryogenic Soils, in: Cryosols, edited by: Kimble, J. M., Springer, Berlin Heidelberg, 347-364, 2004.

Ostroumov, V., Hoover, R., Ostroumova, N., Van Vliet-Lanoë, B., Siegert, C., and Sorokovikov, V.: Redistribution of soluble components during ice segregation in freezing ground, Cold Reg. Sci. Technol., 32, 175-182, 2001.

Palmtag, J., Hugelius, G., Lashchinskiy, N., Tamsdorf, M. P., Richter, A., Elberling, B., and Kuhry, P.: Storage, landscape distribution and burial history of soil organic matter in contrasting areas of continuous permafrost, Arct. Antarct. Alp. Res., 47, 7188, 2015.

Parfitt, R. L. and Childs, C. W.: Estimation of forms of Fe and Al - a review, and analysis of contrasting soils by dissolution and Mössbauer methods, Soil Res., 26, 121-144, 1988.

Ping, C. L., Michaelson, G. J., Kimble, J. M., Romanovsky, V. E., Shur, Y. L., Swanson, D. K., and Walker, D. A.: Cryogenesis and soil formation along a bioclimate gradient in Arctic North America, J. Geophys. Res., 113, G03S12, doi:10.1029/2008JG000744, 2008.

Ping, C. L., Jastrow, J. D., Jorgenson, M. T., Michaelson, G. J., and Shur, Y. L.: Permafrost soils and carbon cycling, SOIL, 1, 147171, doi:10.5194/soil-1-147-2015, 2015.

Rawls, W. J.: Estimating Soil Bulk Density from Particle Size Analysis and Organic Matter Content, Soil Sci., 135, 123-125, 1983.

Rumpel, C. and Kögel-Knabner, I.: Deep soil organic matter a key but poorly understood component of terrestrial C cycle, Plant Soil, 338, 143-158, 2011.

Schaefer, K., Zhang, T., Bruwiler, L., and Barette, A. P.: Amount and timing of permafrost carbon release in response to climate warming, Tellus B, 63, 165-180, 2011.

Scheel, T., Dörfler, C., and Kalbitz, K.: Precipitation of dissolved organic matter by aluminum stabilizes carbon in acidic forest soils, Soil Sci. Soc. Am. J., 71, 64-74, 2007.

Schmidt, M. W. I., Torn, M. S., Abiven, S., Dittmar, T., Guggenberger, G., Janssens, I. A., Kleber, M., Kogel-Knabner, I., Lehmann, J., Manning, D. A. C., Nannipieri, P., Rasse, D. P., Weiner, S., and Trumbore, S. E.: Persistence of soil organic matter as an ecosystem property, Nature, 478, 49-56, 2011.

Schnecker, J., Wild, B., Hofhansl, F., Eloy Alves, R. J., Barta, J., Capek, P., Fuchslueger, L., Gentsch, N., Gittel, A., Guggenberger, G., Hofer, A., Kienzl, S., Knoltsch, A., Lashchinskiy, N., Mikutta, R., Santruckova, H., Shibistova, O., Takriti, M., Urich, T., Weltin, G., and Richter, A.: Effects of Soil Organic Matter Properties and Microbial Community Composition on Enzyme Activities in Cryoturbated Arctic Soils, PLoS ONE, 9, e94076, doi:10.1371/journal.pone.0094076, 2014

Schuur, E. A. G. and Abbott, B.: Climate change: High risk of permafrost thaw, Nature, 480, 32-33, 2011.

Schuur, E. A. G., Bockheim, J., Canadell, J. G., Euskirchen, E., Field, C. B., Goryachkin, S. V., Hagemann, S., Kuhry, P., Lafleur,
P. M., Lee, H., Mazhitova, G., Nelson, F. E., Rinke, A., Romanovsky, V. E., Shiklomanov, N., Tarnocai, C., Venevsky, S., Vogel, J. G., and Zimov, S. A.: Vulnerability of Permafrost Carbon to Climate Change: Implications for the Global Carbon Cycle, Bioscience, 58, 701-714, 2008.

Schuur, E. A. G., Abbott, B. W., Bowden, W. B., Brovkin, V., Camill, P., Canadell, J. G., Chanton, J. P., Iii, F. S. C., Christensen, T. R., Ciais, P., Crosby, B. T., Czimczik, C. I., Grosse, G., Harden, J., Hayes, D. J., Hugelius, G., Jastrow, J. D., Jones, J. B., Kleinen, T., Koven, C. D., Krinner, G., Kuhry, P., Lawrence, D. M., McGuire, A. D., Natali, S. M., O’Donnell, J. A., Ping, C. L., Riley, W. J., Rinke, A., Romanovsky, V. E., Sannel, A. B. K., Schädel, C., Schaefer, K., Sky, J., Subin, Z. M., Tarnocai, C., Turetsky, M. R., Waldrop, M. P., Anthony, K. M. W., Wickland, K. P., Wilson, C. J., and Zimov, S. A.: Expert assessment of vulnerability of permafrost carbon to climate change, Climatic Change, 119, 359-374, doi:10.1007/s10584-013-0730-7, 2013.

Schwertmann, U., Wagner, F., and Knicker, H.: FerrihydriteHumic Associations, Soil Sci. Soc. Am. J., 69, 1009, doi:10.2136/sssaj2004.0274, 2005.

Six, J., Conant, R. T., Paul, E. A., and Paustian, K.: Stabilization mechanisms of soil organic matter: Implications for C-saturation of soils, Plant Soil, 241, 155-176, 2002.

Six, J., Frey, S. D., Thiet, R. K., and Batten, K. M.: Bacterial and Fungal Contributions to Carbon Sequestration in Agroecosystems, Soil Sci. Soc. Am. J., 70, 555-569, doi:10.2136/sssaj2004.0347, 2006.

Smith, L. C., Sheng, Y., MacDonald, G. M., and Hinzman, L. D.: Disappearing Arctic Lakes, Science, 70, 555-569, doi:10.1126/science.1108142, 2005.

Soil Survey Staff: Keys to Soil Taxonomy, 11th Edn., edited by: USDA, United States Department of Agriculture-Natural Resources Conservation Service, Washington DC, 2010.

Sokolov, I. A., Ananko, T. V., and Konyushkov, D. Y.: The Soil Cover of Central Siberia, in: Cryosols, edited by: Kimble, J. M. Springer, Berlin, Heidelberg, 303-338, 2004.

Sushama, L., Laprise, R., Caya, D., Verseghy, D., and Allard, M.: An RCM projection of soil thermal and moisture regimes for North American permafrost zones, Geophys. Res. Lett., 34, L20711, doi:10.1029/2007GL031385, 2007.

Tarnocai, C., Canadell, J., Schuur, E., Kuhry, P., Mazhitova, G., and Zimov, S.: Soil organic carbon pools in the northern circumpolar permafrost region, Global Biogeochem. Cy., 23, GB2023, doi:10.1029/2008GB003327, 2009.

Torn, M. S., Trumbore, S. E., Chadwick, O. A., Vitousek, P. M., and Hendricks, D. M.: Mineral control of soil organic carbon storage and turnover, Nature, 389, 170-173, doi:10.1038/38260, 1997.

UNEP: Policy implications of warming permafrost, edited by: United Nations Environment Programme, United Nations Environment Programme, Nairobi, Kenya, 2012.

USDA: Soil Taxonomy: A Basic System of Classification for Making and Interpeting Soil Surveys, 2nd Edn., United States Department of Agriculture-Natural Resources Conservation Service, Washington, DC, 1999.

Van Vliet-Lanoë, B.: Frost and soils: implications for paleosols, paleoclimates and stratigraphy, Catena, 34, 157-183, 1998.

Von Lützow, M. V., Kögel-Knabner, I., Ekschmitt, K., Matzner, E., Guggenberger, G., Marschner, B., and Flessa, H.: Stabilization of organic matter in temperate soils: mechanisms and their rele- 
vance under different soil conditions - a review, Eur. J. Soil Sci., 57, 426-445, doi:10.1111/j.1365-2389.2006.00809.x, 2006.

Wagai, R. and Mayer, L. M.: Sorptive stabilization of organic matter in soils by hydrous iron oxides, Geochim. Cosmochim. Ac., 71, 25-35, doi:10.1016/j.gca.2006.08.047, 2007.

Whittinghill, K. and Hobbie, S.: Effects of $\mathrm{pH}$ and calcium on soil organic matter dynamics in Alaskan tundra, Biogeochemistry, 111, 569-581, 2012.

Wild, B., Schnecker, J., Bárta, J., Čapek, P., Guggenberger, G., Hofhansl, F., Kaiser, C., Lashchinsky, N., Mikutta, R., Mooshammer, M., Šantrůčková, H., Shibistova, O., Urich, T., Zimov, S. A., and Richter, A.: Nitrogen dynamics in Turbic Cryosols from Siberia and Greenland, Soil Biol. Biochem., 67, 85-93, doi:10.1016/j.soilbio.2013.08.004, 2013.
Wild, B., Schnecker, J., Alves, R. J. E., Barsukov, P., Bárta, J., Čapek, P., Gentsch, N., Gittel, A., Guggenberger, G., Lashchinskiy, N., Mikutta, R., Rusalimova, O., Šantrůčková, H., Shibistova, O., Urich, T., Watzka, M., Zrazhevskaya, G., and Richter, A.: Input of easily available organic $\mathrm{C}$ and $\mathrm{N}$ stimulates microbial decomposition of soil organic matter in arctic permafrost soil, Soil Biol. Biochem., 75, 143-151, doi:10.1016/j.soilbio.2014.04.014, 2014.

Xu, C., Guo, L., Ping, C.-L., and White, D. M.: Chemical and isotopic characterization of size-fractionated organic matter from cryoturbated tundra soils, northern Alaska, J. Geophys. Res., 114, G03002, doi:10.1029/2008JG000846, 2009. 